\title{
Geochemical Characterization of Acid Mine Lakes in Northwest Turkey and Their Effect on the Environment
}

\author{
Deniz Sanliyuksel Yucel · Alper Baba
}

Received: 5 September 2012/Accepted: 5 November 2012/Published online: 6 December 2012

(c) Springer Science+Business Media New York 2012

\begin{abstract}
Mining activity generates a large quantity of mine waste. The potential hazard of mine waste depends on the host mineral. The tendency of mine waste to produce acid mine drainage (AMD) containing potentially toxic metals depends on the amounts of sulfide, carbonate minerals, and trace-element concentrations found in ore deposits. The acid mine process is one of the most significant environmental challenges and a major source of water pollution worldwide. AMD and its effects were studied in northwest Turkey where there are several sedimentary and hydrothermal mineral deposits that have been economically extracted. The study area is located in Can county of Canakkale province. Canakkale contains marine, lagoon, and lake sediments precipitated with volcanoclastics that occurred as a result of volcanism, which was active during various periods from the Upper Eocene to Plio-Quaternary. Can county is rich in coal with a total lignite reserve $>100$ million tons and contains numerous mines that were operated by private companies and later abandoned without any remediation. As a result, human intervention in the natural structure and topography has resulted in large open pits and deterioration in these areas. Abandoned open pit mines typically fill with water from runoff and groundwater discharge, producing artificial lakes. Acid drainage waters from these mines have resulted in the degradation of surface-water quality around Can County. The average $\mathrm{pH}$ and electrical conductivity of acid mine lakes (AMLs) in
\end{abstract}

D. S. Yucel

Department of Geology Engineering, Canakkale Onsekiz Mart University, Canakkale, Turkey

A. Baba $(\square)$

Department of Civil Engineering, Izmir Institute of Technology, Izmir, Turkey

e-mail: alperbaba@iyte.edu.tr this study were found to be 3.03 and $3831.33 \mu \mathrm{S} \mathrm{cm}^{-1}$, respectively. Total iron $(\mathrm{Fe})$ and aluminum $(\mathrm{Al})$ levels were also found to be high $\left(329.77\right.$ and $360.67 \mathrm{mg} \mathrm{L}^{-1}$, respectively). The results show that the concentration of most elements, such as $\mathrm{Fe}$ and $\mathrm{Al}$ in particular, exceed national and international water-quality standards.

Acid mine drainage (AMD) is generally defined as the product formed by the atmospheric oxidation (i.e., by water, oxygen, and carbon dioxide) of relatively common iron $(\mathrm{Fe})$-sulfur minerals, such as pyrite $\left(\mathrm{FeS}_{2}\right)$ and pyrrhotite, in the catalyzing presence of acidithiobacillus ferrooxidans, an acidophilic bacterium, and any other products generated as a consequence of these oxidation reactions (Mills 1995; United States Environmental Protection Agency [USEPA] 1994a, b in Akcil and Koldas 2006; Ozcelik 2007). Generally AMD usually has a low pH and increased concentrations (above background) of dissolved sulfate $\left(\mathrm{SO}_{4}{ }^{2-}\right), \mathrm{Fe}\left(\mathrm{Fe}^{2+}, \mathrm{Fe}^{3+}\right)$, manganese $\left(\mathrm{Mn}^{2+}\right)$, aluminum $\left(\mathrm{Al}^{3+}\right)$, and other metals that result from the oxidation of $\mathrm{FeS}_{2}$ and the dissolution of carbonate, oxide, and aluminosilicate minerals by acidic water (Rose and Cravotta 1998).

The processes that produce AMD are natural, but they are accelerated by mining and can produce large volumes of contaminated effluents. The potential for AMD from mining activities has been known since at least 1556, and acid rock drainage was observed as early as 1698 associated with coal mining in Pennsylvania (British Columbia Acid Mine Drainage Task Force 1989). AMD is an environmental problem that has been studied extensively since the 1950s (Leathen et al. 1953). The causes and formation of AMD as a major source of water-quality degradation (McCleary and Kepler 1994), especially in coal-mining regions, have been 
well documented (Stumm and Morgan 1970; Merritt 1986; Nordstrom and Ball 1986; Erickson and Heiden 1988; Cravotta 1991; Skousen and Ziemkiewicz 1995; Younger 1995; Foos 1997; Nordstrom and Alpers 1998; Rose and Cravotta 1998; Monterroso and Macias 1998; Wood et al. 1999; Pluta and Jackowicz-Korczynski 2003; Kim and Kim 2004; Larsen and Mann 2005; Blodau 2006; Devasahayam 2006; Cravotta 2008; Doulati et al. 2010; Silva et al. 2011a).

As acidic mine water moves through the near surface environment, constituents that are soluble under acidic, oxidizing conditions—-such as $\mathrm{Fe}, \mathrm{Al}, \mathrm{SO}_{4}$, copper $(\mathrm{Cu})$, lead $(\mathrm{Pb})$, zinc $(\mathrm{Zn})$, cadmium $\mathrm{Cd}$, and selenium-become concentrated in the effluent (Anderson and Youngstrom 1976; Davis and Boegly 1981; Brake et al. 2001). The delivery of such acid effluents to streams and rivers can lead to significant environmental impact on sediment and water quality in downstream reservoirs (Salomons 1995; Allan 1997; Paktunc 1999; Sola et al. 2004). AMD is a long-term environmental problem that requires continuous information, monitoring, and long-term performance follow-up, all of which also incur extra costs to the society (Price 2003).

AMD is a recognized problem and is covered in curricula of mining faculties in Turkey. There are very few studies related to AMD except biological ore enrichment, hydrometallurgy, and mine abatement studies (Aytekin and Akdagi 1996; Akcil and Ciftci 2003; Kesimal et al. 2003; Akcil and Koldas 2006; Ozcelik 2007). The district of Can in the Canakkale province in northwest Turkey is rich in lignite. Many small- and medium-sized mining companies have operated lignite mines within the last 32 years. Some of the activities of these enterprises have ceased over time, whereas other mines are still operational. Ceased mining operations have been abandoned without any postclosure methods or rehabilitation. Consequently, human intervention in the natural structure and topography of the surface has resulted in the large open pits and deterioration in these areas. The abandoned open pit mines now contain artificial lakes fed by both surface runoff and underground leakage. High sulfur content of lignite exists in these areas. Over time, these lakes become acidic due to acid generation from $\mathrm{FeS}_{2}$ oxidation. These acid mine lakes (AMLs), near agricultural fields and villages, have low $\mathrm{pH}$ values and high levels of heavy metals and trace elements ( $\mathrm{Al}, \mathrm{Fe}, \mathrm{Mn}$ etc.). This study focuses on the hydrogeochemistry of AML and is a detailed investigation of AMD generation within the wastes produced by mining activities. The effects of these lakes on the environment are also evaluated.

\section{Site Description}

The study area is geographically situated immediately west of Keciagili village, approximately $17 \mathrm{~km}$ southwest of the

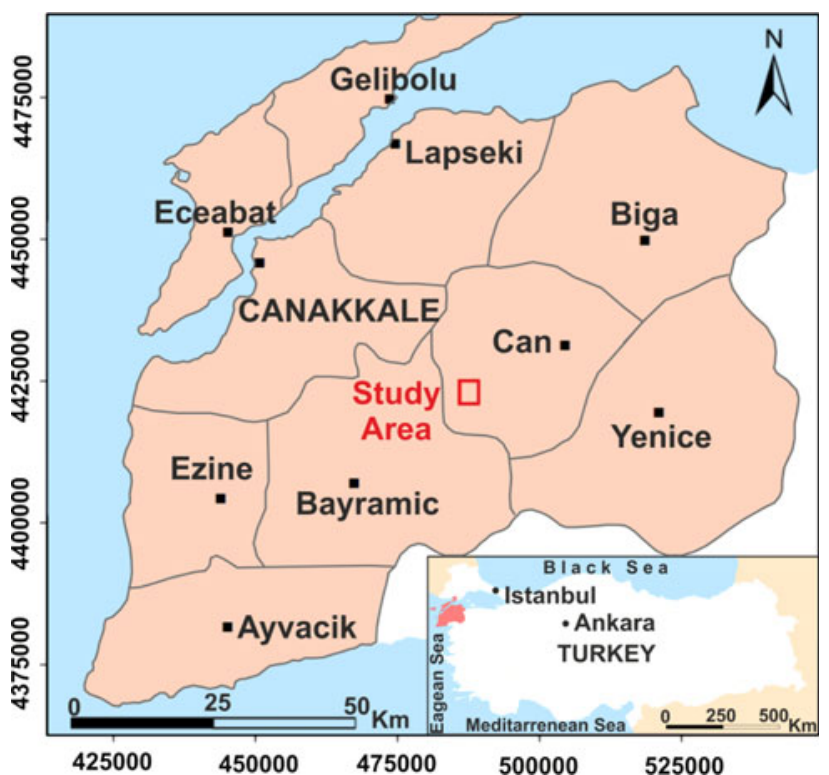

Fig. 1 Location map of the study area

county of Can of Canakkale province on Biga Peninsula in northwest Turkey (see Fig. 1). Climate effects may determine whether a mine discharge is continuous or intermittent, dilute, or highly concentrated, a characteristic that has an effect on the nature of the drainage. The hydraulic characteristics of mine waste may determine the contact time between solid and solution or the proportion of mine waste being flushed. Climatologically, the Canakkale province is situated in a climatic transition between the Mediterranean and Black Sea climate zones. The summers are hot and dry, and the winters are relatively wetter and

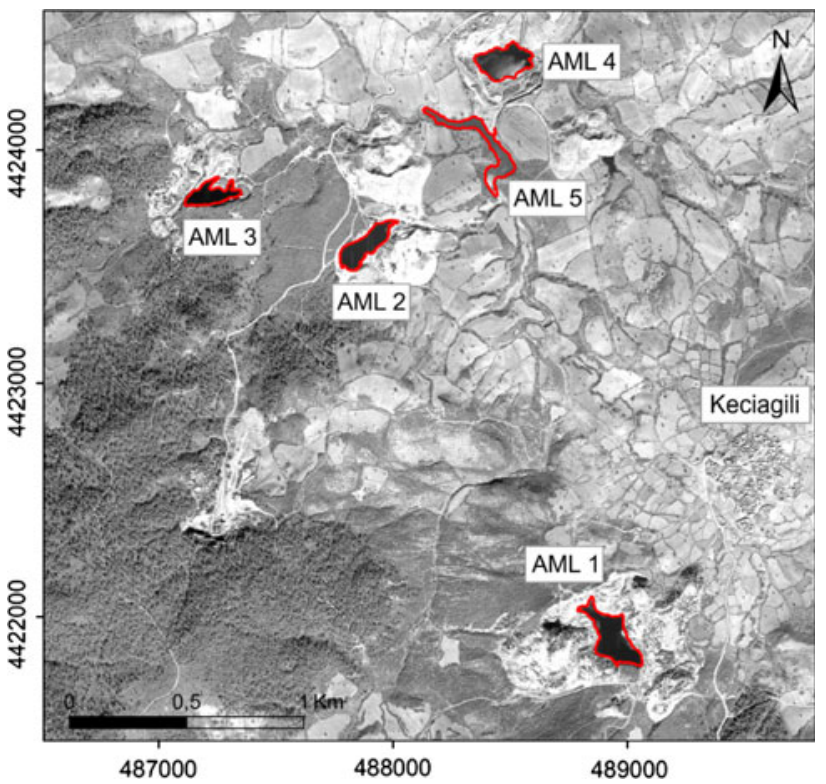

Fig. 2 Satellite imagery AMLs in study area (Worldview-1 [March 2011]) 
Table 1 Basic characteristic of AMLs in the study area

\begin{tabular}{lllllll}
\hline AML no. & Altitude $(\mathrm{m})$ & Area $(\mathrm{da})$ & Perimeter $(\mathrm{m})$ & Mean depth $(\mathrm{m})$ & Water volume $\left(\mathrm{m}^{3}\right)$ & Reference \\
\hline 1 & 245 & 23.81 & 892 & 7.11 & 169289.1 & Okumusoglu (2009) \\
2 & 172 & 15.55 & 616 & 7.41 & 115225.5 & This study, July 2010 \\
3 & 151 & 14.41 & 811 & $\mathrm{NM}$ & $\mathrm{NM}$ & Worldview-1 satellite imagery \\
4 & 140 & 25.54 & 736 & $\mathrm{NM}$ & $\mathrm{NM}$ & (March 2011) \\
5 & 128 & 23.83 & 1465 & $\mathrm{NM}$ & $\mathrm{NM}$ & \\
\hline
\end{tabular}

$N M$ not measured

colder. The long-term (1970-2010) mean annual temperature is $15.16^{\circ} \mathrm{C}$ with a minimum of $-12.1{ }^{\circ} \mathrm{C}$ (February) and a maximum of $39^{\circ} \mathrm{C}$ (July) based on the data collected at Canakkale Meteorological Station (located approximately $45 \mathrm{~km}$ northeast of the study area). North winds are predominant in the region. Precipitation in the region is mostly in the form of rain, and the highest precipitation is observed in winter season. The mean annual precipitation rate was $595.7 \mathrm{~mm}$ between 1970 and 2011 .

$\mathrm{FeS}_{2}$ oxidation and AMD generation are important processes that may take place in the wastes produced by coal-mining and coal-washing operations in Can county. The study area, one of the most polluted acid mine drainage (AMD) sites in Turkey, has many open pit coal mines that operated from 1980 to 2008. However, in 1980s the number of AMLs were increased, but they did not indicate the same increment numerically. It is clear that AMLs have risk due to their presence and areal increments (Yucel et al. 2012).

This study focused on five AMLs (AMLs no. 1 through 5) located immediately west of Keciagili village (Fig. 2). These are small lakes with surface areas not exceeding 25.54 decar (Table 1; Fig. 3a, b). Water levels in these small lakes fluctuate due variations in annual precipitation, evaporation, and drainage patterns. AML no. 1 is the oldest lake, followed by AMLs no. 2, 3, 5, and finally 4 (Yucel and Sanliyuksel Yucel 2012). AML no. 5 is situated on the old stream bed, which was formed as a result of prevention with a huge amount of mine waste.

All of these lakes drain into Kocacay stream, which is the second largest stream in Canakkale province. The hydrology of surface drainage network in Canakkale shows a variable flow regime, which mainly depends on the seasonal precipitation pattern. The main element of the drainage network is the Kocacay stream, which flows northeast through the county of Can and eventually drains into the Sea of Marmara approximately $45-50 \mathrm{~km}$ north of Can.

\section{Geological Setting}

Canakkale is located on the westernmost part of the Biga Peninsula. Biga Peninsula is one of the focal points of current mineral exploration in Turkey (Yigit 2012). Mineral deposits of the Biga peninsula are dominated by volcanic and intrusion-related hydrothermal systems, which is a natural corollary of the preeminent geology (Yigit 2012). Prevalent magmatic and associated volcanic rocks dominate in Biga peninsula. Apart from these plutonic rocks, Biga peninsula is generally made up of a metamorphic and granitic basement (Sengun et al. 2011) and the PermoTriassic Karakaya complex (Okay et al. 1990; Okay and Goncuoglu 2004). Early Eocene-Pliocene-Quaternary
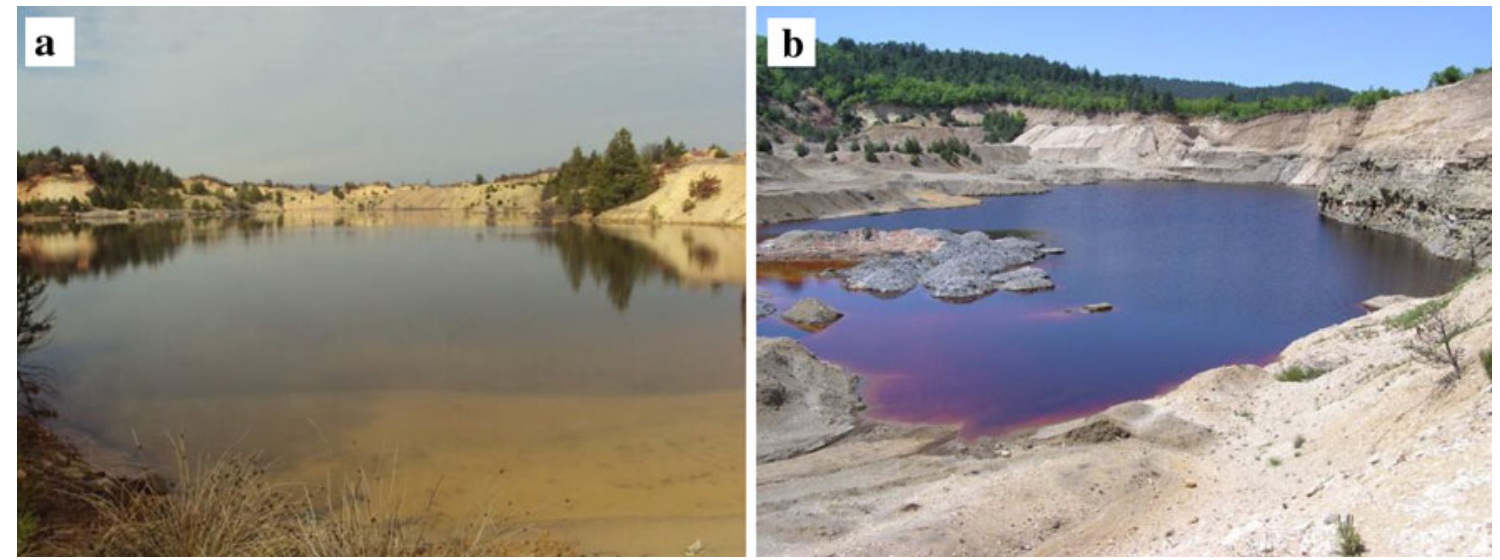

Fig. 3 a Photographs of AMLs no. 1 and b no. 2 


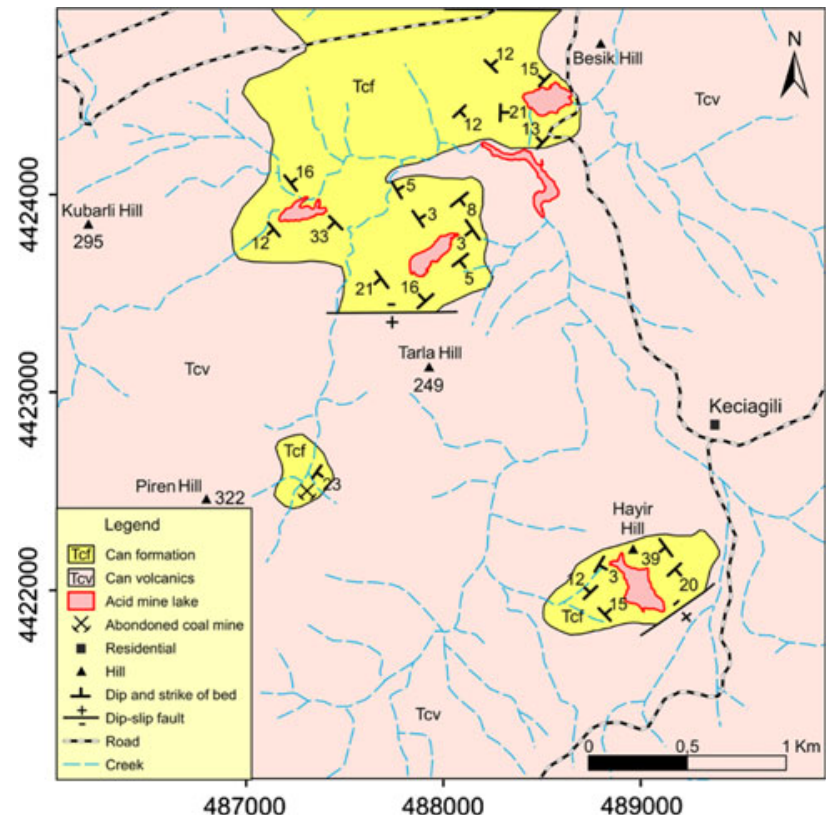

Fig. 4 Geological map of the study area

volcanic and sedimentary rocks form the youngest cover units (Siyako et al. 1989). Cenozoic volcano-plutonic rocks, covering extensive areas, dominate the geology of the Biga peninsula (Yigit 2012). Moreover, Late EoceneMiocene volcanic activity is accompanied by Late Oligocene-Miocene granitic intrusions (Ercan et al. 1995; Delaloye and Bingol 2000; Okay and Satir 2000).

The study area mainly consists of acidic and agglomeratic, andesite, trachyandesite, and andesitic tuff which are named "Can volcanics" by Ercan et al. in 1995). During the Early-Middle Miocene, terrestrial units were deposited along with the calkalkaline volcanic activity (Siyako et al. 1989). These terrestrial units consist of bituminous shale, siltstone, claystone, sandstone, tuff, and coals, named the "Can formation," which is $\leq 250 \mathrm{~m}$ thick and unconformably overlies the Miocene-aged andesitic volcanic rocks (Siyako et al. 1989) (Fig. 4). According to the palynological studies, the coal and claystone of the Can formation were deposited during the late Early Miocene to early Middle Miocene (Middle Orleanian-Early Astaracian [Bozcu et al. 2008]). Early-Middle Miocene times are characterized by coeval volcanism and sedimentation. Lacustrine sediments, such as shale, siltstone, and tuffs, were deposited in small basins, including economic coal deposits, e.g., Can lignite (Yigit 2012). In the Can Basin, the total coal reserves are $>100 \mathrm{Mt}$ (Bozcu et al. 2008) and are exploited mainly by opencast mining in the study area. The Can formation is rich in lignite (also known as brown coal) that is $17 \mathrm{~m}$ thick (Bozcu et al. 2008) and characterized by its low calorific value and high sulfur content. The Can coals are lignite to subbituminous coal (Ro $=0.32-0.44 \%$ ) and have an intermediate to high moisture content ranging from 14.67 to
$28.42 \%$. The ash, volatile matter, and sulphur (S) content (on original basis) vary between 3.48 and $29.83 \%, 26.43$ and $35.81 \%$, and 0.64 and $8.1 \%$, respectively (Gurdal 2008). The major oxides in Can coals are dominated by $\mathrm{SiO}_{2}$ (0.65-20.64\%), $\quad \mathrm{Al}_{2} \mathrm{O}_{3} \quad(0.4-6.09 \%)$, and $\mathrm{Fe}_{2} \mathrm{O}_{3}$ $(0.29-4.09 \%)$ with lesser amounts $(<1.0 \%)$ of $\mathrm{MgO}, \mathrm{CaO}$, $\mathrm{NaO}_{2}, \mathrm{TiO}_{2}, \mathrm{~K}_{2} \mathrm{O}, \mathrm{P}_{2} \mathrm{O}_{5}, \mathrm{MnO}$, and $\mathrm{Cr}_{2} \mathrm{O}_{3}$ (Baba et al. 2007).

Widespread and intense zones of silicified, argillic, and propylitic alterations in the study area can be observed in Can volcanics. These alteration zones give rise to distinct mineral forms. In general, $\mathrm{Al}^{+}$and $\mathrm{K}^{+}$as well as $\mathrm{Mg}^{+}$, $\mathrm{Ca}^{+}$, and $\mathrm{Fe}^{++}$are enriched in argillic and propylitic alteration, respectively (Baba and Gunduz 2010). $\mathrm{Ca}^{+}$, $\mathrm{Mg}^{+}$, and $\mathrm{Fe}^{++}$were leached during argillic alteration, whereas $\mathrm{Na}^{+}$leaching is evident in all alteration types (Sanliyuksel Yucel et al. 2012). The alteration system in the study area displays all porphyry-related alterations, including epithermal and skarn systems, containing porphyry-related high-sulphidation style gold $(\mathrm{Au})$ and $\mathrm{Cu}-\mathrm{Au}$ mineralization (Yigit 2012). The alteration preserves the texture with feldspars altering to kaolinites and smectites, with the groundmass being replaced by varying degrees of silica. A surficial argillic alteration zone has developed on weathered outcrops due to the oxidation of $\mathrm{FeS}_{2} . \mathrm{FeS}_{2}$ is the most abundant primary sulfide mineral related to $\mathrm{Au}$ in the prospect (Yigit 2012). $\mathrm{FeS}_{2}$ is a common mineral in abandoned coal mines, especially around Keciagili village. $\mathrm{FeS}_{2}$ oxidation and AMD generation are important processes that may take place within the wastes produced by coal mining operations in study area.

\section{Materials and Methods}

\section{Geochemistry and Mineralogy of the Study Area}

Mine wastes and sedimentary and volcanic rocks were analyzed for major element content and chemical characteristics. The mineralogical characteristics of mine waste and soils are the most important factor of AMD quality. It is therefore critical to evaluate the mineralogical characteristics of a mine waste. Mine wastes having much greater surface area than undisturbed geologic material due to their smaller grain size and are more prone to generating AMD. Because large masses of sulfide minerals are exposed quickly during the mining and milling processes, the surrounding environment can often not attenuate the resulting low pH conditions (Jennings et al. 2008). Therefore, mine wastes were collected around Keciagili village to evaluate the mineralogical characteristics of mine wastes. All samples were analyzed by inductively coupled plasma-mass spectrometry (ICP-MS) at ACME Labs (Canada). 
The morphology of the mine waste and bottom sediment at the macro and micro levels were obtained by microscopy. Scanning electron microscopy (SEM) (FEI Philips XL30 sFEG, OR) coupled with energy-dispersive X-ray spectrometry (EDX) were performed using secondary electrons (SE) and back-scattered electrons (BSE) detectors to determine surface features and local chemical contents. X-ray diffraction (XRD) analyses of the samples were performed on a Philips X'Pert diffractometer and in a Debye-Scherrer camera. XRD was performed on samples pulverized in alcohol for $3 \mathrm{~min}$ in a McCrone micronizer equipped with agate grinding pellets. The powder patterns were collected with a Scintag X1 automated powder diffractometer equipped with a Peltier detector having $\mathrm{CuK} \alpha$ radiation. The XRD patterns were analyzed with the use of Material Data Inc.'s JADE software and standard reference patterns. Waste and sediment samples were analyzed at the Center for Material Science at the Izmir Institute of Technology, Turkey.

\section{Hydrogeochemistry of AMLs}

The five AMLs, from which water samples were taken, were monitored from 2009 to 2012 in the study area. In all AMLs, water was sampled. In addition, a 9 m-deep vertical-depth profile was sampled and measured at AML no. 2. Water samples were filtered through $0.45-\mu \mathrm{m}$ filter paper, transferred to $50-\mathrm{mL}$ polyethylene bottles. and stored at $4{ }^{\circ} \mathrm{C}$ without acidification. All water samples were collected in duplicate. The samples were analyzed for major cations, anions, heavy metals, and trace elements. Major and trace elements were analyzed with ICP-MS, and $\mathrm{SO}_{4}$ was analyzed by ion chromatography at ACME Labs (Canada). Physical parameters $(\mathrm{pH}$, redox potential, temperature, salinity, and electrical conductivity) were also measured in situ using a multiparameter probe (WTW 340i).

Based on the results of the bathymetry study and the characteristics of the general lake morphology of AML no. 2 , sampling locations were identified on the lake surface. The locations of these sampling points always coincided with some of the bathymetry points. In general, the aim was to achieve a relatively homogenous distribution of sampling points within the lake's surface area. Waterquality samples were then collected from all stations with a Niskin sampling bottle (HydroBios) with a capacity of $5 \mathrm{~L}$. The bottle was made from hard plastic materials to avoid cross-contamination from metal ions. Although surface samples were collected directly into polyethylene sampling bottles, all other samples were obtained with this equipment. All of collected data was transferred to a geographic information system (GIS) platform (ArcGIS v9.3) for data visualization and interpretation.

\section{Results and Discussion}

\section{Geochemical Data}

The geochemistry of the mineral-water interaction is dependent on the geologic setting. The potential sources for the generation of AMD are reactive sulphide minerals and their oxidation products. The production and persistence of acidity largely depends on the nature of the sulphide mineral being oxidized, the reaction mechanism (i.e., oxygen $v s$. ferric $\mathrm{Fe}$ as the oxidant), and the presence of acid-consuming minerals, such as carbonates and aluminosilicates.

A coal-rock sampling campaign was also conducted in the vicinity of the AMLs sampled. A total of 10 samples were collected from volcanic and sedimentary rocks, coal, and mine wastes and analysed for major element constituents (Table 2). $\mathrm{SiO}_{2}, \mathrm{Al}_{2} \mathrm{O}_{3}$, and $\mathrm{Fe}_{2} \mathrm{O}_{3}$ constitute the other important parts of the rocks, with maximum values reaching as high as $61.25,19.97$, and $10.46 \%$, respectively.

Mineralogy and petrography data were also used to examine sulphide mineralogy in the study area. The most common sulphide mineral is $\mathrm{FeS}_{2}$, which is the mineral of most relevance from an acid-generation perspective. The Greek philosopher Theophrastus (approximately 325 BC) recognized the oxidation of $\mathrm{FeS}_{2}$, the formation of metal salts, and the production of acid (Lottermoser 2010). $\mathrm{FeS}_{2}$ produces AMD, and, generally, crystals are $<3 \mathrm{~mm}$ in size, yellowish brown in color, and highly lustrous in the study area.

$\mathrm{FeS}_{2}$ oxidation is directly controlled by the mineral and crystal type (Malmstrom et al. 2000) and by particle size, i.e., mass normalized surface area (Stromberg and Banwart 1999). Morrison (1988) defined nine classes of $\mathrm{FeS}_{2}$ morphology, with end members having framboidal and euhedral crystal structures. Framboidal $\mathrm{FeS}_{2}$ consists of aggregates of very small $\mathrm{FeS}_{2}$ crystals $(<1 \mu \mathrm{m})$, whereas euhedral crystals are generally greater (tens to thousands of microns). Among a variety of morphologies, such as framboids, octahedral, and cubic crystals with irregular surfaces, the small, polycrystalline framboids are particularly susceptible to oxidation owing to their porosity and large surface area (Evangelou and Zhang 1995). $\mathrm{FeS}_{2}$ crystals have a cubic crystal form in coals in the study area (Fig. 5) containing $69.60 \%$ sulfur and $30.40 \% \mathrm{Fe}$ (Fig. 6).

Neutralization reactions play a key role in determining the compositional characteristics of drainage originating from sulphide oxidation. Most carbonate minerals are capable of dissolving rapidly, thus making them an effective acid neutralizer. Calcite is more easily dissolved than other carbonate minerals. Dissolved calcite neutralizes acid 
Table 2 Major element oxides of rocks in study area (\%)

\begin{tabular}{llllllllllllll}
\hline Rock type & $\mathrm{SiO}_{2}$ & $\mathrm{Al}_{2} \mathrm{O}_{3}$ & $\mathrm{Fe}_{2} \mathrm{O}_{3}$ & $\mathrm{MgO}$ & $\mathrm{CaO}$ & $\mathrm{Na}_{2} \mathrm{O}$ & $\mathrm{K}_{2} \mathrm{O}$ & $\mathrm{TiO}_{2}$ & $\mathrm{P}_{2} \mathrm{O}_{5}$ & $\mathrm{MnO}^{2}$ & $\mathrm{Cr}_{2} \mathrm{O}_{3}$ & $\mathrm{LOI}^{2}$ & $\mathrm{Sum}^{2}$ \\
\hline Coal & 24.18 & 8.28 & 10.19 & 0.18 & 9.28 & 0.85 & 0.44 & 0.12 & 0.1 & $<0.01$ & $<0.002$ & 45.6 & 99.19 \\
Coal & 40.4 & 19.97 & 10.46 & 0.49 & 0.37 & 0.21 & 0.38 & 0.72 & 0.18 & 0.66 & 0.003 & 26 & 99.88 \\
Claystone & 51.35 & 19.81 & 2.96 & 0.93 & 3.75 & 0.35 & 1.76 & 0.64 & 0.41 & $<0.01$ & $<0.002$ & 17.8 & 99.79 \\
Claystone & 61.25 & 14.8 & 2.34 & 0.71 & 0.31 & 0.36 & 0.36 & 0.56 & 0.31 & 0.01 & 0.003 & 18.8 & 99.81 \\
Mine waste & 44.61 & 14.13 & 5.57 & 2.09 & 0.22 & 1.14 & 0.93 & 0.64 & 0.14 & $<0.002$ & $<0.004$ & 29.17 & 98.64 \\
Mine waste & 35.51 & 13.6 & 3.93 & 1.79 & 0.37 & 1.25 & 1.29 & 0.39 & 0.09 & 0.01 & $<0.004$ & 40.85 & 99.08 \\
Andesite & 58.9 & 17.77 & 6.63 & 0.98 & 3.65 & 2.77 & 3.22 & 0.79 & 19 & 0.04 & 0.003 & 4.8 & 99.76 \\
Andesite & 56.99 & 19.49 & 7.39 & 0.44 & 0.67 & 0.91 & 4.23 & 0.71 & 0.1 & 0.09 & 0.004 & 8.7 & 99.74 \\
Andesite & 56.89 & 19.85 & 3.1 & 0.75 & 1.55 & 1.59 & 3.56 & 0.84 & 0.12 & $<0.01$ & 0.005 & 11.5 & 99.76 \\
Trachyandesite & 58.31 & 17.64 & 7.37 & 0.5 & 4.97 & 3.18 & 3.18 & 0.7 & 0.21 & 0.06 & 0.002 & 3.7 & 99.8 \\
\hline
\end{tabular}
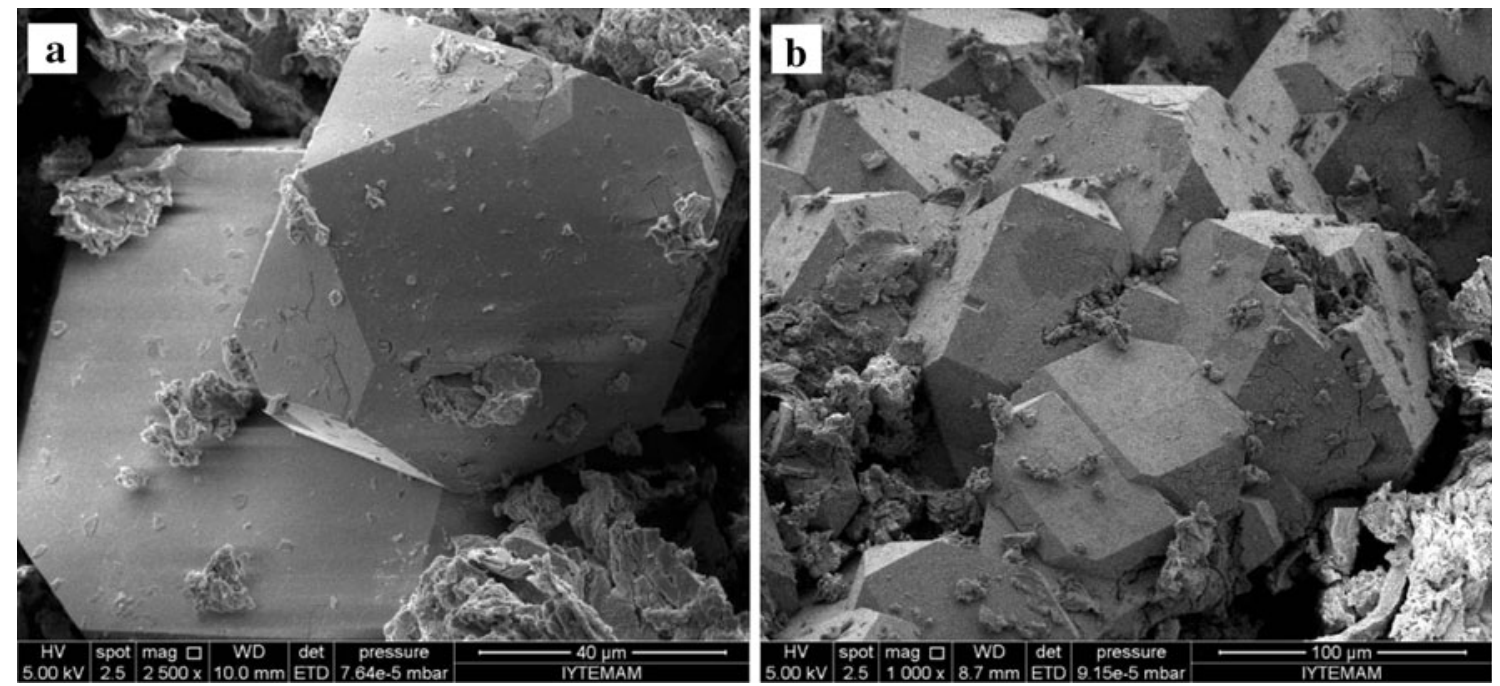

Fig. 5 SEM photomicrographs showing cubic $\mathrm{FeS}_{2}$ crystals in coal (crystal structures are. a pentagondodekaeder and b pyritoeder)

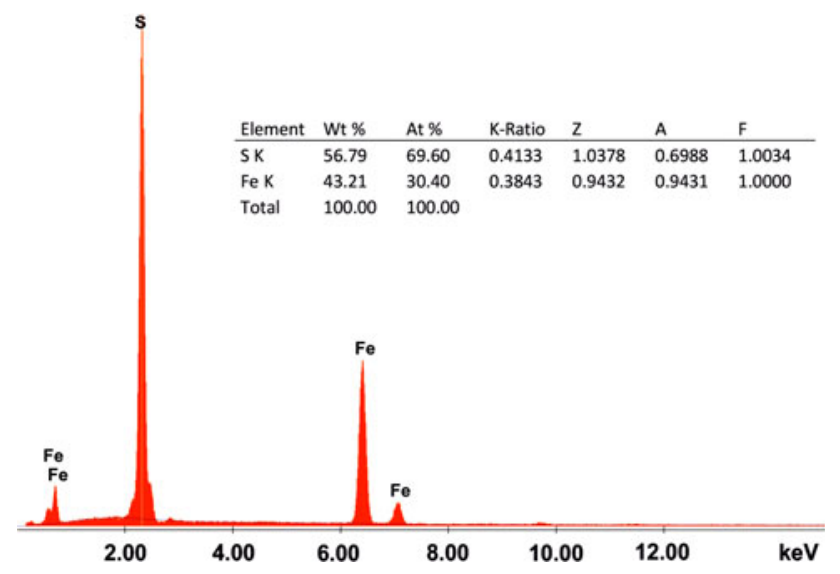

Fig. 6 EDX results of cubic $\mathrm{FeS}_{2}$ crystals

by complexing with hydrogen ions to form bicarbonate and carbonic acid (Stumm and Morgan 1995). Calcareous minerals are the dominant components of fractures in claystone, shale, and associated strata of coal-bearing rocks in Keciagili village.

The major reservoir for buffering capacity in the environment is silicate minerals, which make up the majority of the minerals found in the Earth's crust (Lottermoser 2010). Chemical weathering of silicate minerals consumes hydrogen ions and occurs by way of congruent or incongruent weathering (Lottermoser 2010). Dissolution of silicates, such as plagioclase-feldspars and olivine, can also neutralize acid (Lapakko 2002). However, their rates of dissolution and consequent acid neutralization are slow relative to the carbonate minerals (Nesbitt and Jambor 1998). Feldspar, labradorite, quartz, orthoclase, and mica are silicate minerals and can be detected by XRD analysis in mine waste. The clay minerals also occurred as in association with $\mathrm{FeS}_{2}$ and calcite. The XRD analyses performed detected illite, smectite, were also observed in the SEM analyses (Fig. 7).

Secondary minerals are important in water-mineral reaction and result from weathering of primary sulphide 


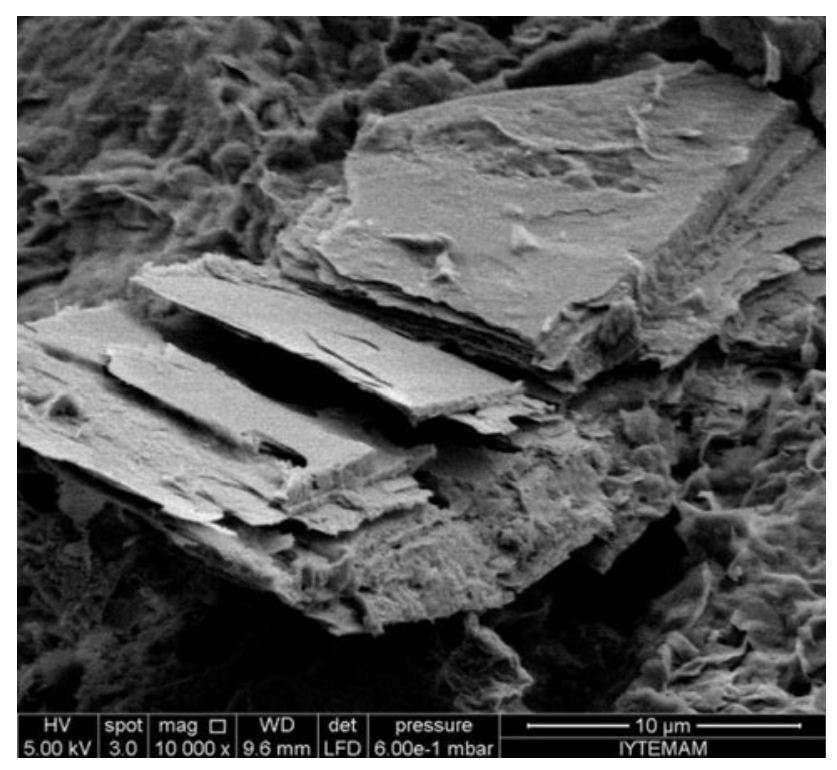

Fig. 7 SEM photomicrographs showing clay minerals in claystone minerals. Secondary minerals are younger than the rock inn which they form (Neuendorf et al. 2005). Some of these secondary minerals may have deleterious effects on water quality because of the release of additional acidity during their formation (e.g., metal (hydro)oxides) or release of stored acidity, sulphate, or metals (or both) during their dissolution (e.g., Fe and $\mathrm{Al}$ hydroxysulphates). The formation of secondary minerals is the most common form of element fixation in porewaters of sulfidic wastes (Lottermoser 2010). A significant fraction of the metals released by sulfide oxidation is retained in the wastes as the secondary mineral precipitates (Lin 1997; Lin and Herbert 1997; Lottermoser 2010).

Mineralogical studies of AMD sites indicate that gypsum is the most common sulfate phase controlling sulfate concentrations in such environments (Davis et al. 1991; Jambor and Blowes 1994). Gypsum was found in tailings in Keciagili village (Fig. 8a-c). The gypsum formed during the earlier stages of AMD generation and dissolved as a
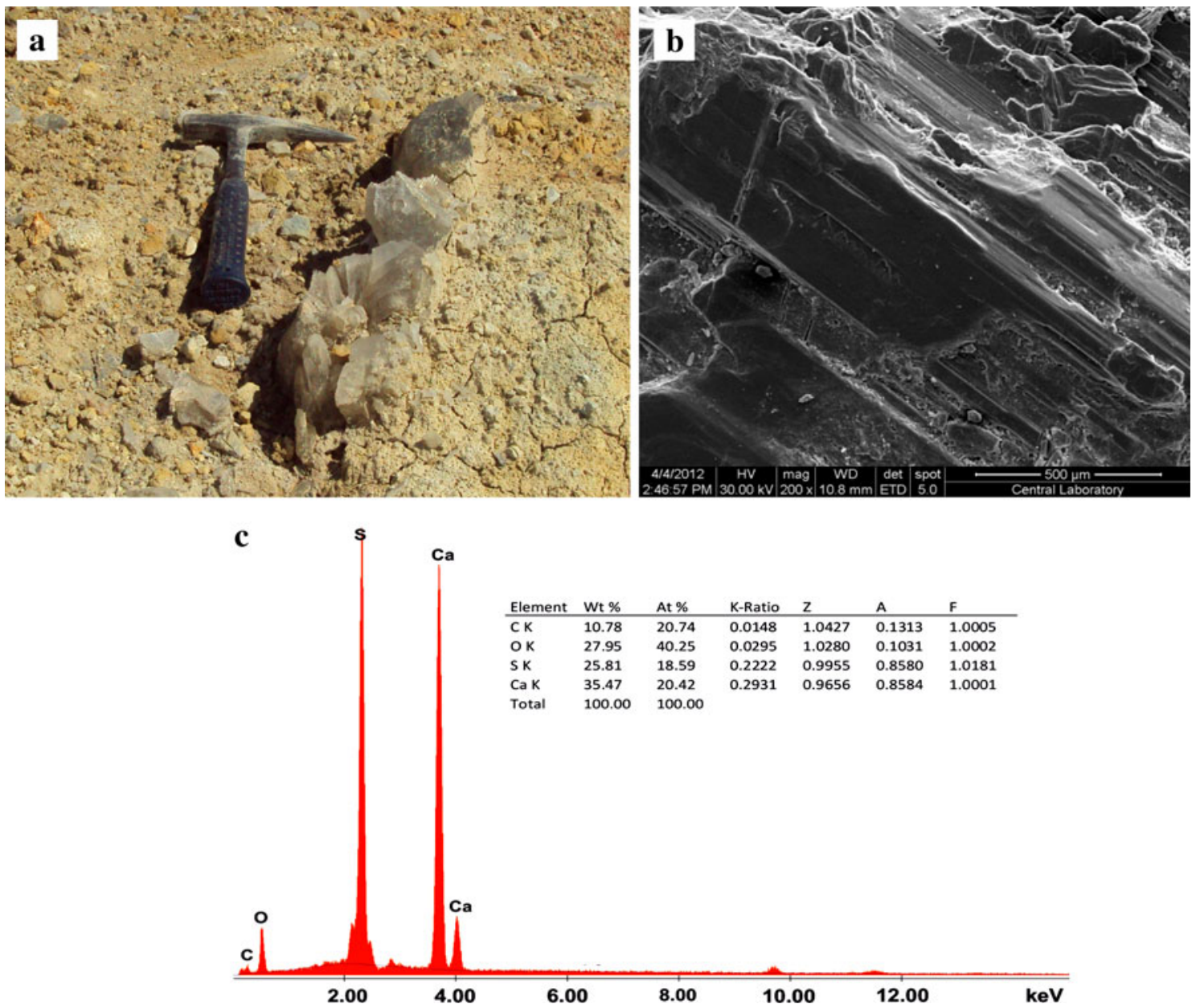

Fig. 8 a Field view and $\mathbf{b}$ SEM image showing gypsum and $\mathbf{c}$ its EDX analysis 
Fig. 9 XRD result of bottom sediment

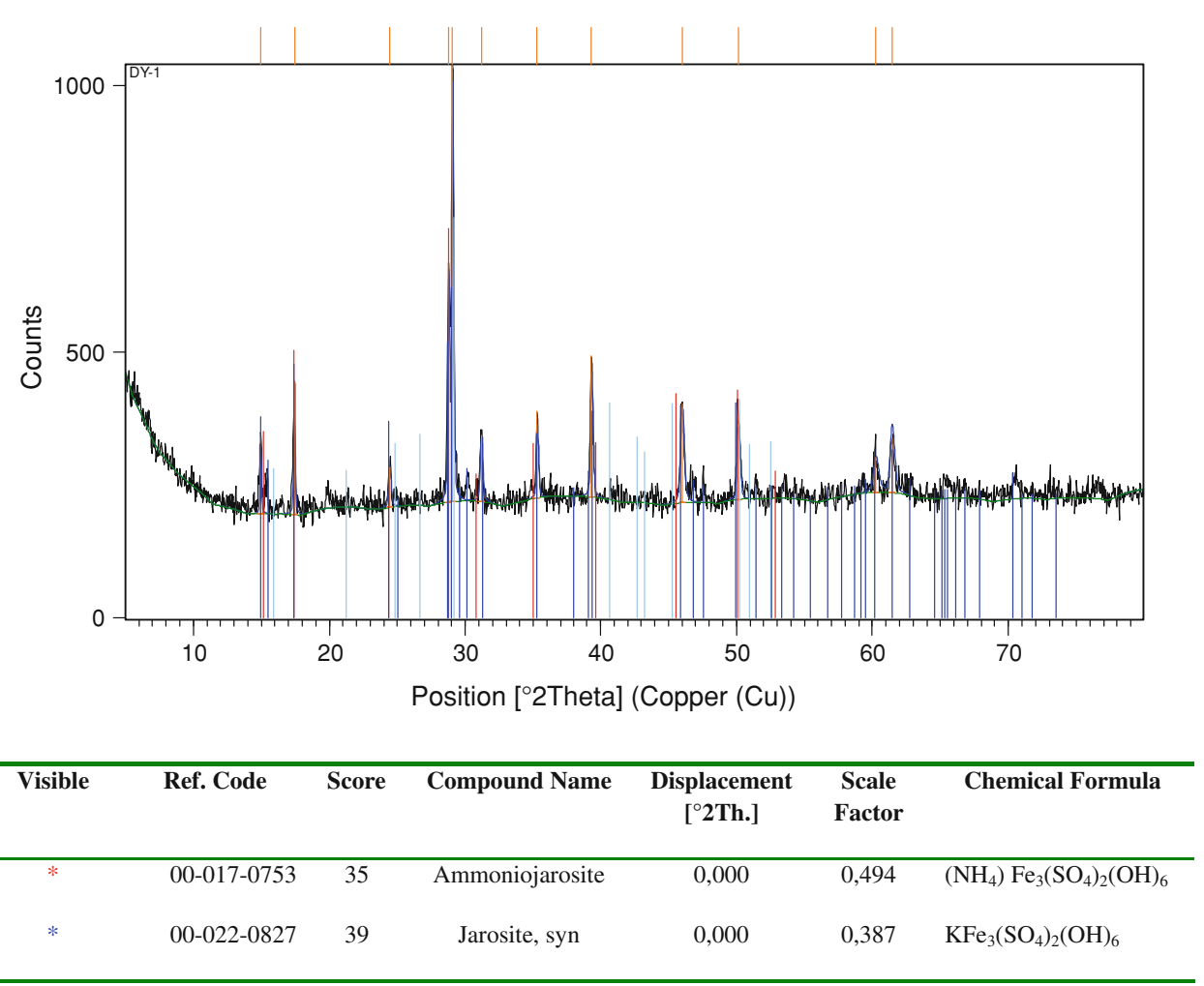

consequence of low calcium $(\mathrm{Ca})$ concentration in porewater. Sulfate was flushed out of the tailings pile.

Jarosite and amoniojarosite are the main secondary minerals in bottom sediment (Fig. 9). Jarosite is a strawyellow mineral that is common in the weathered zone of sulfide ore deposits and in acid sulfate soils. Jarosite is less soluble than the other acid-producing sulfate minerals. Jarosite commonly occurs intimately mixed with clays in seams and in thick clay beds (Dutrizac and Jambor 2000). The general assumption is that the Fe and sulfate originate from the oxidation of $\mathrm{FeS}_{2}$, whereas acid leaching of the clay minerals provides the alkalies (Warshaw 1956). The $\mathrm{FeS}_{2}$ may occur within the clay (Krazewski 1972; Goldbery 1978), thereby generating the ferric sulfate solutions in situ. Alternatively, the jarosite could have precipitated directly, such as from ponded solutions (Gryaznov 1957; Alpers et al. 1992; Long et al. 1992), or the solutions could have been transported into the sedimentary unit from distal sources (Khlybov 1976; Dutrizac and Jambor 2000). Jarosite can assume a cubic morphology, suggesting that it forms as a pseudomorph after $\mathrm{FeS}_{2}$ (Silva et al. 2011b).
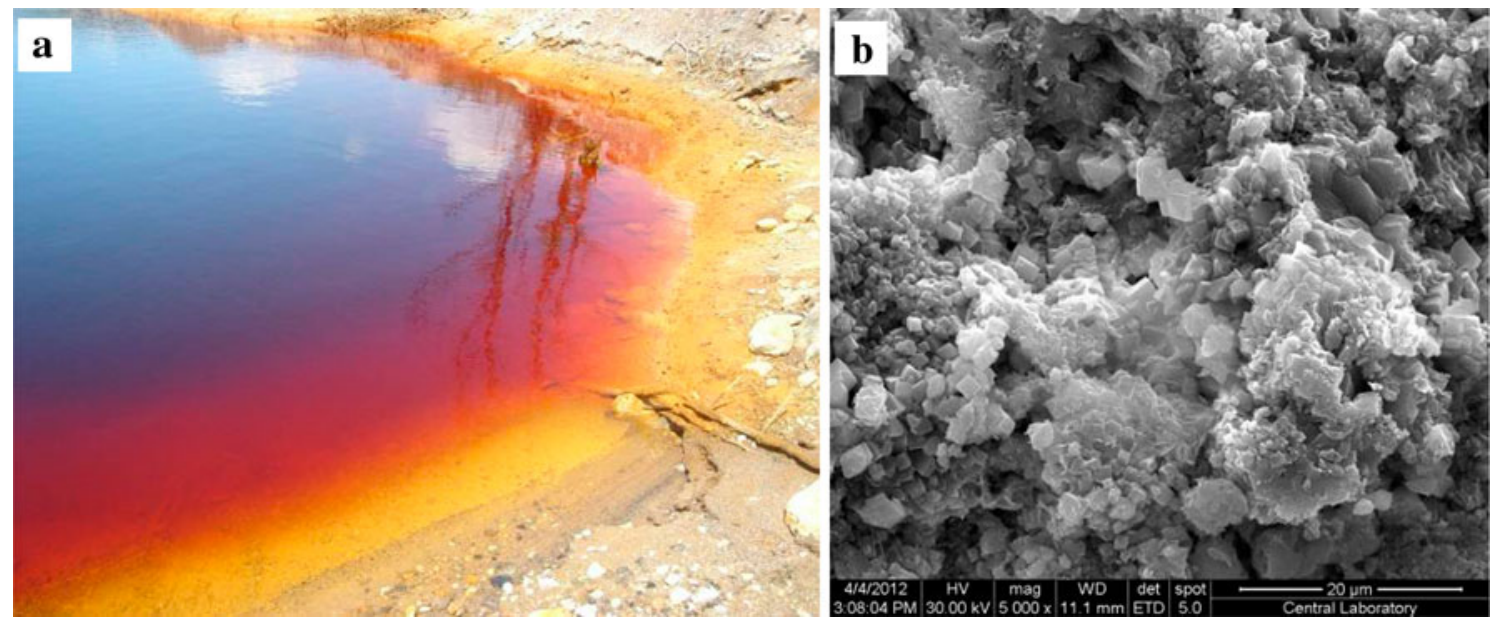

Fig. 10 a Field view and b SEM photomicrographs showing pseudocubic jarosite crystals 




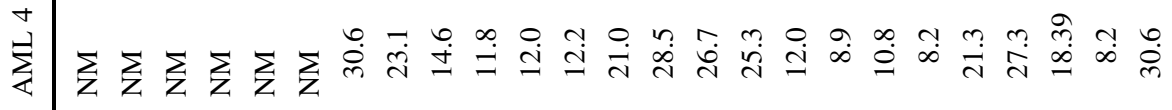

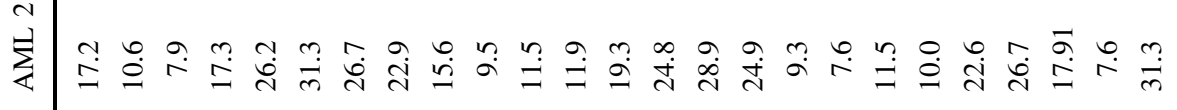



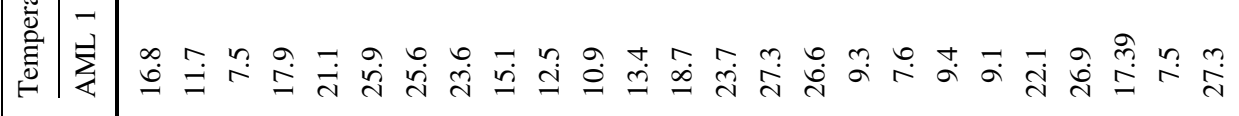

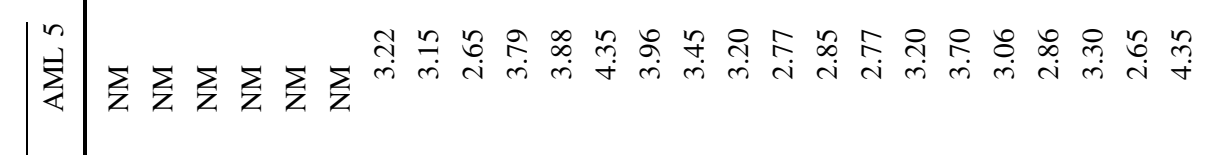

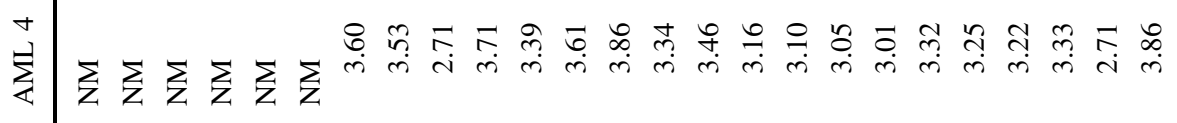

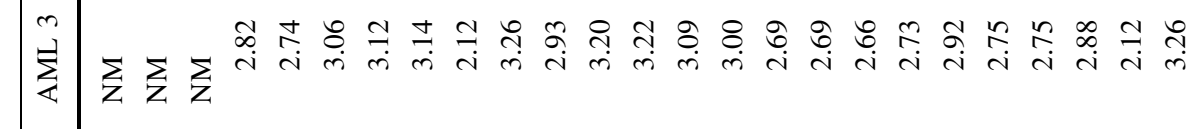

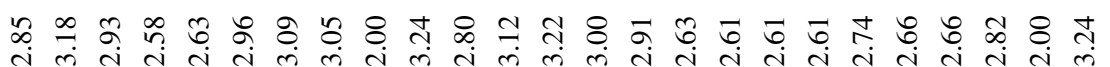

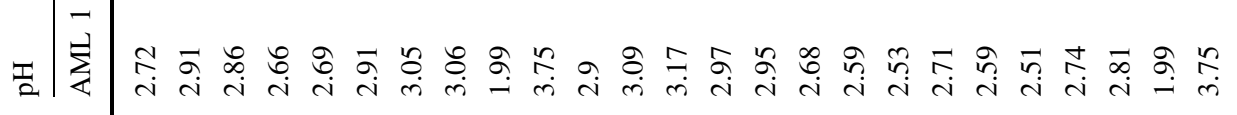



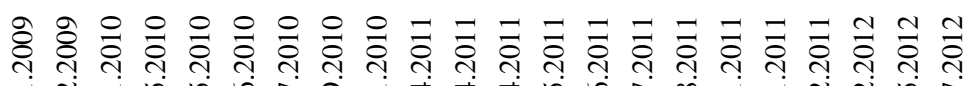

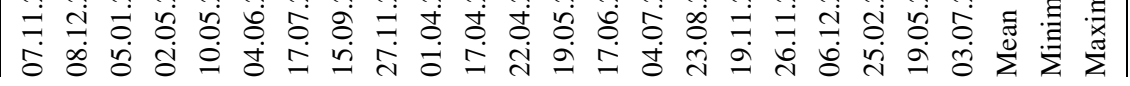




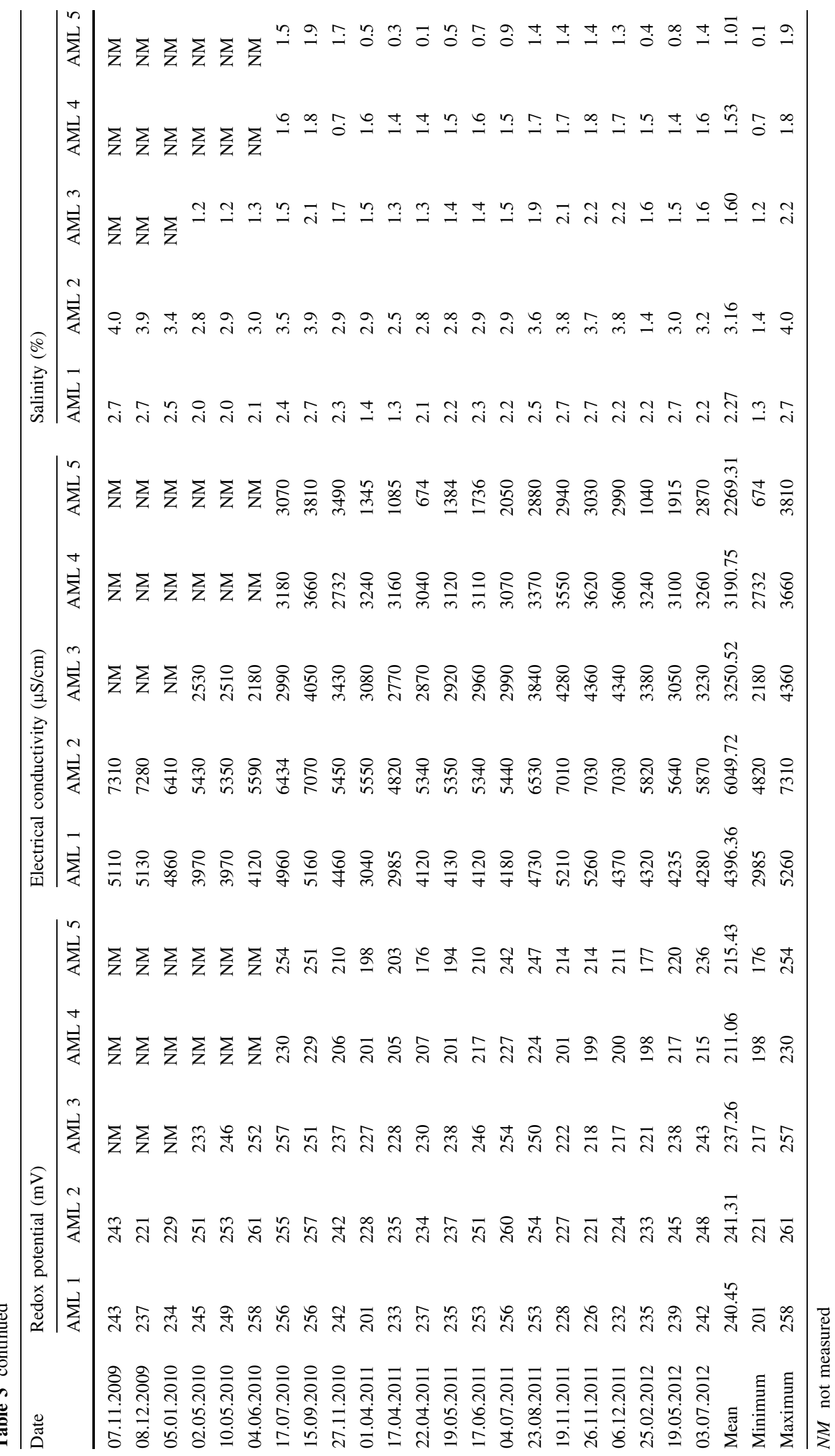


Fig. 11 Time versus $\mathrm{pH}$ values of AMLs

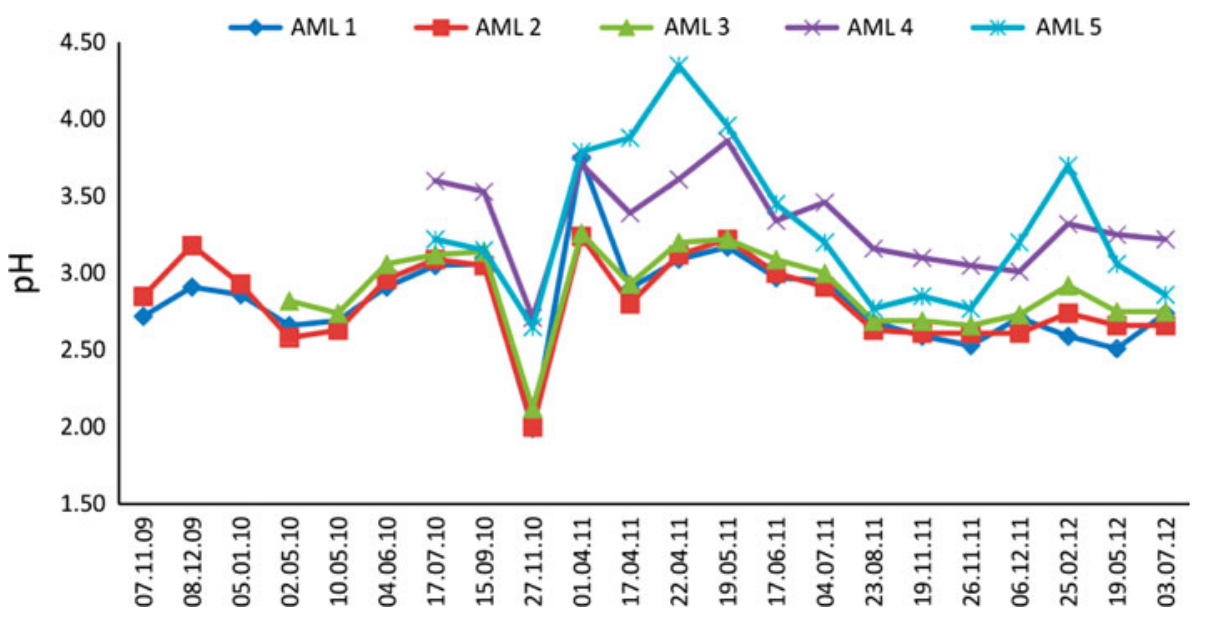

Figure 10 shows a field view and SEM image of jarosite pseudomorph after $\mathrm{FeS}_{2}$.

The formation of ammoniojarosite is rare in nature because of the scarcity of concentrated ammonium-bearing solutions (Dutrizac and Jambor 2000). The ammonium originates from the decomposition of organic substances, whereas the $\mathrm{Fe}$ and sulfate are derived from the oxidation of associated $\mathrm{FeS}_{2}$. Aside from the scarcity of $\mathrm{NH}_{4}$-rich solutions, the $\mathrm{K}^{+}: \mathrm{NH}_{4}{ }^{+}$partition coefficient strongly favors the formation of jarosite rather than ammoniojarosite (Dutrizac and Jambor 2000).

\section{Hydrogeochemical Data}

The oxidation of $\mathrm{FeS}_{2}$, a common form of sulfur bearing $\mathrm{Fe}$ mineral associated with coal, often results in the formation of AMD, which typically forms extremely acidic lakes in the depressions of abandoned open-pit mines (Gunduz et al. 2007). The process of $\mathrm{FeS}_{2}$ oxidation is complex and involves both chemical and biological mechanisms as well as a number of controls (Blodau 2006). The reaction of $\mathrm{FeS}_{2}$ with oxygen and water produces a solution of ferrous sulfate and sulfuric acid. Ferrous Fe can further be oxidized producing additional acidity.

AMLs are commonly observed in Germany (Blodau et al. 1998; Abel et al. 2000; Weber 2000; Lessmann et al. 2003), Greece (Triantafyllidis and Skarpelis 2006), and the United States (Shevenell et al. 1999; Nordstorm et al. 2000). A number of such lakes were also recently discovered in the Can coal basin located in Canakkale province in northwestern Turkey where sulfur-rich lignite is extracted by way of surface mining operations (Gunduz et al. 2007; Baba et al. 2009).

\section{Field Parameters}

The field parameter results of AML measurements are listed in Table 3. These results show that the $\mathrm{pH}$ of AMLs ranged from 1.99 to 4.35 between 2009 and 2012 (Fig. 11). The generation of low $\mathrm{pH}$ is attributed to sulfide oxidation found primarily in $\mathrm{FeS}_{2}$ and, to a certain extent, in other sulfide minerals (Blodau 2006). The $\mathrm{pH}$ of AMD can be unstable because of a general tendency for the exsolution of dissolved $\mathrm{CO}_{2}$ and $\mathrm{H}_{2} \mathrm{~S}$, the dissolution of $\mathrm{O}_{2}$, and the
Fig. 12 Time versus EC values of AMLs




Table 4 Major cation values of AMLs $\left(\mathrm{mg} \mathrm{L}^{-1}\right)$

\begin{tabular}{|c|c|c|c|c|c|c|c|c|c|c|}
\hline \multirow{2}{*}{$\begin{array}{l}\text { Major cations } \\
\text { Date }\end{array}$} & \multicolumn{5}{|l|}{$\mathrm{Na}^{+}$} & \multicolumn{5}{|l|}{$\mathrm{K}^{+}$} \\
\hline & AML 1 & AML 2 & AML 3 & AML 4 & AML 5 & AML 1 & AML 2 & AML 3 & AML 4 & AML 5 \\
\hline 08.12.2009 & 125.51 & 279.69 & $\mathrm{NM}$ & $\mathrm{NM}$ & $\mathrm{NM}$ & 0.99 & 2.93 & NM & $\mathrm{NM}$ & $\mathrm{NM}$ \\
\hline 17.07.2010 & 104.8 & 164.27 & 53.02 & $\mathrm{NM}$ & $\mathrm{NM}$ & 0.99 & 0.99 & 3.36 & $\mathrm{NM}$ & $\mathrm{NM}$ \\
\hline 01.04.2011 & 115.92 & 176.93 & 76.93 & 216.15 & 44.39 & 1.90 & 1.90 & 2.09 & 9.94 & 9.10 \\
\hline 19.05 .2011 & 96.3 & 181.65 & 74.92 & 207.73 & 52.14 & 1.40 & 0.87 & 2.30 & 10.07 & 6.21 \\
\hline 04.07.2011 & 108.8 & 168.30 & 98.60 & 265.70 & 81.21 & 1.60 & 2.00 & 4.80 & 15.80 & 12.41 \\
\hline 06.12 .2011 & 105.38 & 164.17 & 87.49 & 217.03 & 48.11 & 1.80 & 2.94 & 4.30 & 8.82 & 16.57 \\
\hline 25.02 .2012 & 77.01 & 157.97 & 108.52 & 243.13 & 43.97 & 0.95 & 2.00 & 2.00 & 12.00 & 4.78 \\
\hline 03.07 .2012 & 81.43 & 146.60 & 137.55 & 197.72 & 50.41 & 1.25 & 2.89 & 2.70 & 7.14 & 5.88 \\
\hline Mean & 101.89 & 179.94 & 91.00 & 224.57 & 53.37 & 1.36 & 2.06 & 3.07 & 10.62 & 9.15 \\
\hline Minimum & 77.01 & 146.60 & 53.02 & 197.72 & 43.97 & 0.95 & 0.87 & 2.00 & 7.14 & 4.78 \\
\hline Maximum & 125.51 & 279.69 & 137.55 & 265.70 & 81.21 & 1.90 & 2.94 & 4.80 & 15.80 & 16.57 \\
\hline 08.12.2009 & 232.53 & 261.55 & $\mathrm{NM}$ & $\mathrm{NM}$ & NM & 444.25 & 513.84 & NM & $\mathrm{NM}$ & $\mathrm{NM}$ \\
\hline 17.07.2010 & 230.53 & 230.53 & 63.25 & NM & NM & 377.65 & 477.65 & 98.51 & NM & $\mathrm{NM}$ \\
\hline 01.04 .2011 & 178.10 & 278.10 & 98.53 & 125.43 & 49.67 & 350.70 & 450.70 & 147.28 & 386.49 & 122.06 \\
\hline 19.05 .2011 & 198.40 & 238.17 & 64.69 & 101.00 & 34.40 & 392.80 & 470.20 & 177.89 & 315.80 & 107.70 \\
\hline 04.07.2011 & 228.90 & 357.80 & 80.60 & 119.40 & 62.61 & 478.10 & 520.10 & 229.00 & 411.30 & 172.10 \\
\hline 06.12 .2011 & 174.21 & 306.63 & 69.08 & 101.88 & 73.95 & 304.34 & 451.29 & 212.02 & 306.87 & 145.53 \\
\hline 25.02 .2012 & 182.00 & 306.00 & 92.00 & 118.00 & 28.74 & 356.10 & 461.90 & 245.10 & 368.80 & 85.47 \\
\hline 03.07 .2012 & 134.40 & 271.20 & 68.48 & 94.97 & 53.61 & 290.20 & 445.30 & 177.55 & 302.30 & 141.30 \\
\hline Mean & 194.88 & 281.24 & 76.66 & 110.11 & 50.49 & 374.20 & 473.87 & 183.90 & 348.59 & 129.02 \\
\hline Minimum & 134.40 & 230.53 & 63.25 & 94.97 & 28.74 & 290.20 & 445.30 & 98.51 & 302.30 & 85.47 \\
\hline Maximum & 232.53 & 357.80 & 98.53 & 125.43 & 73.95 & 478.10 & 520.10 & 245.10 & 411.30 & 172.10 \\
\hline
\end{tabular}

$N M$ not measured

Table 5 Major anion values of AMLs $\left(\mathrm{mg} \mathrm{L}^{-1}\right)$

\begin{tabular}{|c|c|c|c|c|c|c|c|c|c|c|c|c|c|c|c|}
\hline \multirow{2}{*}{$\begin{array}{l}\text { Major } \\
\text { cations } \\
\text { Date }\end{array}$} & \multicolumn{5}{|l|}{$\mathrm{F}^{-}$} & \multicolumn{5}{|l|}{$\mathrm{Cl}^{-}$} & \multicolumn{5}{|l|}{$\mathrm{SO}_{4}{ }^{2-}$} \\
\hline & $\begin{array}{l}\text { AML } \\
1\end{array}$ & $\begin{array}{l}\text { AML } \\
2\end{array}$ & $\begin{array}{l}\text { AML } \\
3\end{array}$ & $\begin{array}{l}\text { AML } \\
4\end{array}$ & $\begin{array}{l}\text { AML } \\
5\end{array}$ & $\begin{array}{l}\text { AML } \\
1\end{array}$ & $\begin{array}{l}\text { AML } \\
2\end{array}$ & $\begin{array}{l}\text { AML } \\
3\end{array}$ & $\begin{array}{l}\text { AML } \\
4\end{array}$ & $\begin{array}{l}\text { AML } \\
5\end{array}$ & AML 1 & AML 2 & AML 3 & AML 4 & AML 5 \\
\hline 08.12 .2009 & 2.94 & 2.45 & NM & NM & NM & 44.63 & 100.84 & NM & NM & NM & 3857.26 & 5296.00 & NM & NM & NM \\
\hline 17.07.2010 & 1.40 & 1.40 & 3.10 & NM & NM & 78.30 & 78.30 & 39.80 & NM & NM & 3512.40 & 5012.40 & 903.80 & NM & NM \\
\hline 01.04 .2011 & 1.12 & 1.12 & 2.65 & 1.20 & 1.30 & 73.20 & 73.20 & 38.75 & 99.41 & 104.56 & 3017.26 & 5017.26 & 988.63 & 1018.45 & 895.00 \\
\hline 19.05 .2011 & 1.89 & 1.30 & 1.29 & 1.55 & 1.58 & 53.60 & 182.42 & 48.67 & 83.54 & 65.87 & 3192.50 & 5273.24 & 1455.12 & 1823.67 & 772.24 \\
\hline 04.07.2011 & 2.98 & 2.77 & 2.91 & 1.80 & 1.70 & 63.00 & 143.00 & 69.00 & 106.00 & 72.00 & 3000.00 & 4600.00 & 1500.00 & 1700.00 & 1000.00 \\
\hline 06.12 .2011 & 4.12 & 3.68 & 4.80 & 2.27 & 3.24 & 65.33 & 191.45 & 73.90 & 89.25 & 85.27 & 3122.16 & 4413.20 & 1656.70 & 1036.76 & 964.55 \\
\hline 25.02 .2012 & 3.05 & 3.02 & 3.09 & 2.10 & 3.12 & 46.00 & 97.00 & 67.00 & 100.00 & 54.00 & 3260.00 & 5370.00 & 2520.00 & 1760.00 & 594.00 \\
\hline 03.07 .2012 & 1.71 & 2.76 & 1.48 & 3.76 & 1.93 & 42.78 & 83.01 & 44.28 & 76.16 & 53.84 & 3181.56 & 4774.08 & 2330.27 & 1605.84 & 1091.64 \\
\hline Mean & 2.40 & 2.31 & 2.76 & 2.11 & 2.14 & 58.35 & 118.65 & 54.48 & 92.39 & 72.59 & 3267.89 & 4969.52 & 1622.07 & 1490.78 & 886.23 \\
\hline Minimum & 1.12 & 1.12 & 1.29 & 1.20 & 1.30 & 42.78 & 73.20 & 38.75 & 76.16 & 53.84 & 3000.00 & 4413.20 & 903.80 & 1018.45 & 594.00 \\
\hline Maximum & 4.12 & 3.68 & 4.80 & 3.76 & 3.24 & 78.30 & 191.45 & 73.90 & 106.00 & 104.56 & 3857.26 & 5370.00 & 2520.00 & 1823.67 & 1091.64 \\
\hline
\end{tabular}

$N M$ not measured

consequent oxidation and hydrolysis of dissolved $\mathrm{Fe}$ and Mn (Rose and Cravotta 1998; Cravotta et al. 1999). The electrical conductivity (EC) values of AMLs ranged between 674 and $7310 \mu \mathrm{S} / \mathrm{cm}$ (Fig. 12). These values were consistent with EC values of numerous AMLs published in the literature (Lessmann et al. 1999; Espana et al. 2008). 
Table 6 Heavy-metal and trace-element values of AMLs $\left(\mu \mathrm{gL}^{-1}\right)$

\begin{tabular}{|c|c|c|c|c|c|c|c|c|c|c|c|c|}
\hline & $\mathrm{Al}$ & As & $\mathrm{Cd}$ & Co & $\mathrm{Cr}$ & $\mathrm{Cu}$ & $\mathrm{Fe}$ & $\mathrm{Mn}$ & $\mathrm{Ni}$ & $\mathrm{Pb}$ & S & $\mathrm{Zn}$ \\
\hline \multicolumn{13}{|l|}{ AML no. 1: Date } \\
\hline 08.12 .2009 & 278245 & 3.9 & 14.16 & 2030 & 26 & 340.6 & 88093 & 74630 & 1009 & 1.67 & 1350000 & 4666 \\
\hline 17.07.2010 & 247950 & 4.1 & 20 & 1270 & 19 & 220 & 90315 & 67760 & 520 & 1.6 & 1289000 & 2820 \\
\hline 01.04 .2011 & 252683 & 5.2 & 21.3 & 1938 & 33.75 & 312.84 & 83739 & 72413 & 1071 & 1.95 & 1511000 & 4471 \\
\hline 04.07 .2011 & 286613 & 6 & 15 & 2150 & 20 & 365 & 91903 & 83947 & 1075 & 2 & 1275000 & 4881 \\
\hline 06.12 .2011 & 204677 & 4.5 & 16 & 1784 & 25 & 197.89 & 90108 & 64201 & 515 & 1.8 & 1434000 & 3569 \\
\hline 25.02 .2012 & 219618 & 2.9 & 13.8 & 1524 & 23 & 196.4 & 54198.9 & 66489 & 579 & 1.3 & 1206000 & 2758 \\
\hline 03.07 .2012 & 201450 & 3.1 & 11.2 & 1100 & 17 & 190 & 75580 & 67610 & 493 & 1.1 & 1318000 & 2990 \\
\hline Mean & 241605.14 & 4.24 & 15.92 & 1685.14 & 23.39 & 260.39 & 81990.98 & 71007.14 & 751.71 & 1.63 & 1340428.6 & 3736.42 \\
\hline Minimum & 201450 & 2.9 & 11.2 & 1100 & 17 & 190 & 54198.9 & 64201 & 493 & 1.1 & 1206000 & 2758 \\
\hline Maximum & 286613 & 6 & 21.3 & 2150 & 33.75 & 365 & 91903 & 83947 & 1075 & 2 & 1511000 & 4881 \\
\hline EPA (2003) & 200 & 10 & 5 & - & 100 & 1000 & 300 & 50 & - & 15 & - & 5000 \\
\hline WHO (2004) & 200 & 10 & 5 & - & 50 & 2000 & 200 & 400 & 20 & 10 & - & 5000 \\
\hline ITASHY (2005) & 200 & 10 & 5 & - & 50 & 2000 & 200 & 50 & 20 & 10 & - & 5000 \\
\hline \multicolumn{13}{|l|}{ AML no. 2: Date } \\
\hline 08.12 .2009 & 311980 & 14.9 & 29.1 & 4781 & 40 & 645 & 284540 & 206430 & 2150 & 0.4 & 1796000 & 16270 \\
\hline 17.07.2010 & 345800 & 16.2 & 21.8 & 4290 & 43 & 610 & 328296 & 217935 & 2436 & 0.5 & 1991400 & 15481 \\
\hline 01.04 .2011 & 327510 & 12.9 & 19.3 & 4954 & 39 & 486 & 227210 & 225650 & 1800 & 0.25 & 1851000 & 15730 \\
\hline 19.05 .2011 & 346624 & 15.3 & 20.9 & 3820 & 41 & 590 & 270414 & 208360 & 2396 & 0.4 & 1898000 & 13117 \\
\hline 04.07.2011 & 360675 & 12.1 & 27.9 & 4245 & 51 & 952 & 329770 & 187079 & 2367 & 0.5 & 1932000 & 12037 \\
\hline 06.12 .2011 & 352699 & 17.7 & 26.2 & 4087 & 57 & 457 & 277169 & 222585 & 2149 & 0.3 & 1839000 & 15013 \\
\hline 25.02 .2012 & 308835 & 11.4 & 25.9 & 3918 & 45 & 420 & 154650 & 182203 & 2022 & 0.44 & 2084000 & 10281 \\
\hline 03.07 .2012 & 356310 & 14.9 & 18.7 & 3460 & 34 & 511 & 284400 & 216580 & 1840 & 0.1 & 2125000 & 9610 \\
\hline Mean & 338804.12 & 14.42 & 23.73 & 4194.37 & 43.75 & 583.87 & 269556.13 & 208352.75 & 2145 & 0.36 & 1939550 & 13442.37 \\
\hline Minimum & 308835 & 11.4 & 18.7 & 3460 & 34 & 420 & 154650 & 182203 & 1800 & 0.1 & 1796000 & 9610 \\
\hline Maximum & 360675 & 17.7 & 29.1 & 4954 & 57 & 952 & 329770 & 225650 & 2436 & 0.5 & 2125000 & 16270 \\
\hline EPA (2003) & 200 & 10 & 5 & - & 100 & 1000 & 300 & 50 & - & 15 & - & 5000 \\
\hline WHO (2004) & 200 & 10 & 5 & - & 50 & 2000 & 200 & 400 & 20 & 10 & - & 5000 \\
\hline ITASHY (2005) & 200 & 10 & 5 & - & 50 & 2000 & 200 & 50 & 20 & 10 & - & 5000 \\
\hline \multicolumn{13}{|l|}{ AML no. 3: Date } \\
\hline 17.07.2010 & 118745 & 6.1 & 20.6 & 835 & 94 & 143 & 27780 & 24010 & 510 & 2.1 & 577000 & 2370 \\
\hline 01.04 .2011 & 124792 & 5.3 & 19 & 1220 & 150 & 190 & 28721 & 25650 & 578 & 1.9 & 612380 & 1896 \\
\hline 19.05 .2011 & 123639 & 5.9 & 11.43 & 1317 & 87 & 103 & 31790 & 20213 & 614 & 1.5 & 657300 & 2015 \\
\hline 04.07 .2011 & 129498 & 5 & 12.5 & 1168 & 96 & 155 & 34370 & 27574 & 580 & 1 & 682000 & 1238 \\
\hline 06.12 .2011 & 142765 & 6.2 & 15.78 & 1289 & 146 & 152 & 31951 & 24322 & 502 & 1.8 & 786400 & 2211 \\
\hline 25.02 .2012 & 155878 & 7.1 & 17.2 & 1316 & 133 & 79 & 21550 & 33820 & 563 & 2 & 914000 & 3923 \\
\hline 03.07 .2012 & 166730 & 6.3 & 11.63 & 780 & 78 & 101 & 35962 & 21370 & 437 & 1.3 & 1143800 & 3120 \\
\hline Mean & 137435.28 & 5.98 & 15.44 & 1132.14 & 112 & 131.86 & 30303.43 & 25279.86 & 540.57 & 1.65 & 764413.33 & 2396.14 \\
\hline Minimum & 118745 & 5 & 11.43 & 780 & 78 & 79 & 21550 & 20213 & 437 & 1 & 577000 & 1238 \\
\hline Maximum & 166730 & 7.1 & 20.6 & 1317 & 150 & 190 & 35962 & 33820 & 614 & 2.1 & 1143800 & 3923 \\
\hline EPA (2003) & 200 & 10 & 5 & - & 100 & 1000 & 300 & 50 & - & 15 & - & 5000 \\
\hline WHO (2004) & 200 & 10 & 5 & - & 50 & 2000 & 200 & 400 & 20 & 10 & - & 5000 \\
\hline ITASHY (2005) & 200 & 10 & 5 & - & 50 & 2000 & 200 & 50 & 20 & 10 & - & 5000 \\
\hline \multicolumn{13}{|l|}{ AML no. 4: Date } \\
\hline 01.04 .2011 & 20600 & 2.37 & 6.9 & 930 & 4 & 210 & 9670 & 35480 & 410 & 0.7 & 585600 & 1720 \\
\hline 19.05 .2011 & 19687 & 2.95 & 4.7 & 836 & 1.7 & 174 & 9645 & 38603 & 429.6 & 0.9 & 597490 & 1549 \\
\hline 04.07.2011 & 16884 & 4 & 6.2 & 819.3 & 4 & 114 & 7142 & 32737 & 354 & 3 & 613700 & 1607 \\
\hline 06.12 .2011 & 19783 & 3.2 & 5.5 & 713.4 & 1.4 & 132 & 7588 & 31546 & 321 & 0.4 & 653860 & 1982 \\
\hline
\end{tabular}


Table 6 continued

\begin{tabular}{|c|c|c|c|c|c|c|c|c|c|c|c|c|}
\hline & $\mathrm{Al}$ & As & $\mathrm{Cd}$ & Co & $\mathrm{Cr}$ & $\mathrm{Cu}$ & $\mathrm{Fe}$ & $\mathrm{Mn}$ & $\mathrm{Ni}$ & $\mathrm{Pb}$ & $\mathrm{S}$ & $\mathrm{Zn}$ \\
\hline 25.02 .2012 & 18262 & 2.8 & 8.1 & 719 & 2.3 & 76 & 9856 & 32509 & 229 & 0.3 & 726000 & 611 \\
\hline 03.07 .2012 & 20531 & 2.7 & 4.2 & 669 & 1.1 & 69 & 8563 & 30850 & 210 & 0.1 & 734900 & 790 \\
\hline Mean & 19291.8 & 3 & 5.93 & 781.11 & 2.41 & 129.16 & 8744 & 33620.83 & 325.6 & 0.9 & 651925 & 1376.5 \\
\hline Minimum & 16884 & 2.37 & 4.2 & 669 & 1.1 & 69 & 7142 & 30850 & 210 & 0.1 & 585600 & 611 \\
\hline Maximum & 20600 & 4 & 8.1 & 930 & 4 & 210 & 9856 & 38603 & 429.6 & 3 & 734900 & 1982 \\
\hline EPA (2003) & 200 & 10 & 5 & - & 100 & 1000 & 300 & 50 & - & 15 & - & 5000 \\
\hline WHO (2004) & 200 & 10 & 5 & - & 50 & 2000 & 200 & 400 & 20 & 10 & - & 5000 \\
\hline ITASHY (2005) & 200 & 10 & 5 & - & 50 & 2000 & 200 & 50 & 20 & 10 & - & 5000 \\
\hline \multicolumn{13}{|l|}{ AML no. 5: Date } \\
\hline 01.04 .2011 & 36810 & 3.05 & 3 & 210 & 1.9 & 18 & 15680 & 12240 & 110 & 2.2 & 286000 & 960 \\
\hline 19.05.2011 & 38940 & 3.3 & 2.4 & 275 & 1.73 & 16.48 & 17004 & 11876 & 148 & 1.5 & 295400 & 764 \\
\hline 04.07 .2011 & 62880 & 2.1 & 2.39 & 468.2 & 2 & 27.7 & 25335 & 19978 & 183 & 1 & 393000 & 1238 \\
\hline 06.12 .2011 & 41339 & 3.1 & 2.03 & 328 & 1.76 & 13.28 & 18188 & 18200 & 139 & 0.8 & 201500 & 930 \\
\hline 25.02 .2012 & 18192 & 2.9 & 1.05 & 150.3 & 0.5 & 12.9 & 12330 & 9880 & 77 & 0.4 & 173000 & 438 \\
\hline 03.07 .2012 & 51494 & 2.67 & 0.9 & 350 & 0.3 & 11.7 & 14590 & 18290 & 112 & 0.1 & 387500 & 1210 \\
\hline Mean & 41609.16 & 2.85 & 1.96 & 296.91 & 1.36 & 16.67 & 17187.83 & 15077.33 & 128.17 & 1 & 289400 & 923.33 \\
\hline Minimum & 18192 & 2.1 & 0.9 & 150.3 & 0.3 & 11.7 & 12330 & 9880 & 77 & 0.1 & 173000 & 438 \\
\hline Maximum & 62880 & 3.3 & 3 & 468.2 & 2 & 27.7 & 25335 & 19978 & 183 & 2.2 & 393000 & 1238 \\
\hline EPA (2003) & 200 & 10 & 5 & - & 100 & 1000 & 300 & 50 & - & 15 & - & 5000 \\
\hline WHO (2004) & 200 & 10 & 5 & - & 50 & 2000 & 200 & 400 & 20 & 10 & - & 5000 \\
\hline ITASHY (2005) & 200 & 10 & 5 & - & 50 & 2000 & 200 & 50 & 20 & 10 & - & 5000 \\
\hline
\end{tabular}

Eh values are likely to be meaningful in high-Fe and lowpH waters (Nordstrom et al. 1979; Sracek et al. 2004). Eh values of AMLs are between 176 and $261 \mathrm{mV}$. The Eh values probably reflect the variations in the dominant $\mathrm{Fe}^{2 \pm}$ $\mathrm{Fe}^{3+}$ redox couple because concentrations of $\mathrm{Fe}$ were generally high. In general, temperature of surface waters change with geographical location, altitude, season, time of day, and depth of water body (Sracek et al. 2004).

\section{Water Chemistry}

Sulfate is the predominant anion in all of AMLs in the study area. Sulfate levels were observed to range between 594 and $5370 \mathrm{mg} \mathrm{L}^{-1}$ (mean 2447.30), which exceeds the water-quality standard of $250 \mathrm{mg} \mathrm{L}^{-1}$ by a factor of 10 (USEPA 2003; World Health Organization [2004]; ITASHY 2005) (Table 4). Similar values have been measured in other AMLs worldwide (Bachmann et al. 2001; Triantafyllidis and Skarpelis 2006; Espana et al. 2008). Mg and $\mathrm{Ca}$ values ranged between 28.74 and 357.8 and between 85.47 and $520.1 \mathrm{mg} \mathrm{L}^{-1}$, respectively (Table 5).

Most metals have increasing ionic solubility under acidic and oxidizing conditions. A typical attenuation sequence for AMD in surface water is described in Plumlee (1999). When AMD enters a stream, it is progressively diluted, which causes an increase in $\mathrm{pH}$. This leads to precipitation of the typical orange ferric (hydr)oxide colloids and coatings commonly observed in acidic mine effluents. As the $\mathrm{pH}$ of the water continues to increase, $\mathrm{Al}$ and $\mathrm{Mg}$ precipitates form because sorption onto the suspended $\mathrm{Fe}, \mathrm{Mn}$, and $\mathrm{Al}$ particulates becomes more effective.

$\mathrm{Fe}$ and $\mathrm{Al}$ are the most predominant metal species in AMLs in the study area. Similar values have been measured in other AMLs worldwide (Silva et. 2011a; Brake et al. 2001; Bladau 2006; Espana et al. 2008). High Fe levels are typically characteristic of $\mathrm{FeS}_{2}$ oxidation. $\mathrm{Fe}$ concentrations ranged between 7.14 and $329.77 \mathrm{mg} \mathrm{L}^{-1}$ (Table 6). The concentration of $\mathrm{Al}$ was between 16.88 and $360.67 \mathrm{mg} \mathrm{L}^{-1}$. The observed high aluminum concentrations are also a clue for the high clay content of the coals and regional rocks. High S concentrations were found in all five lakes, the maximum of which reached a level as high as $2125 \mathrm{mg} \mathrm{L}^{-1}$. The high $\mathrm{S}$ concentrations are no surprise because it has been well known that Can coals contain high $\mathrm{S}$ contents. These lakes also have extremely high concentrations of manganese, which were observed to range between 9.88 and $225.65 \mathrm{mg} \mathrm{L}^{-1}$. Manganese contents are closely related to the lithology and the abundance of clay minerals. All of these values exceed the ITASHY (2005), United States Environmental Protection Agency (2003) and WHO (2004) water-quality standards value. 

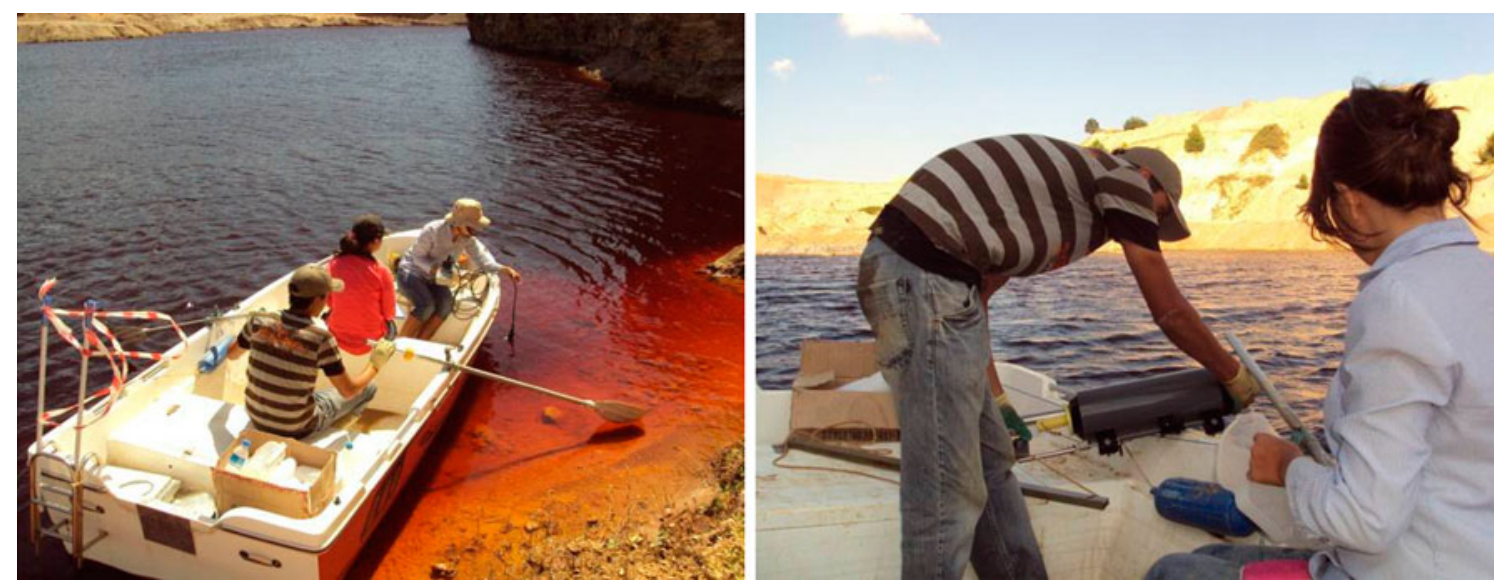

Fig. 13 Snapshots from AML no. 2 during field work

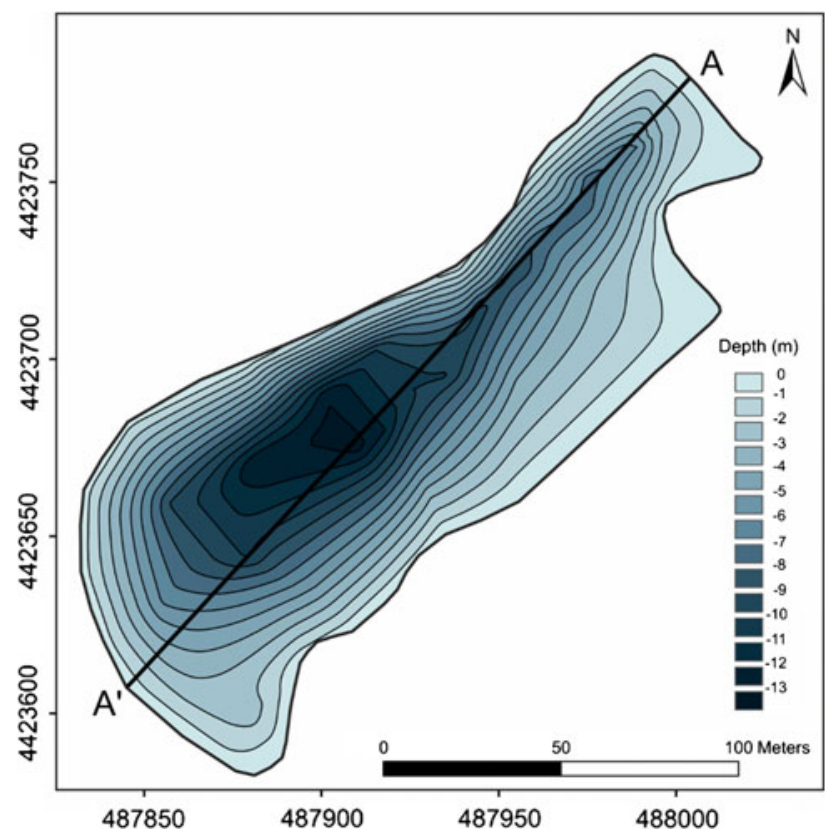

Fig. 14 Bathymetry of AML no. 2 (July 2010)

Maximum and minimum nickel concentration in AMLs were measured to be 2436 and $77 \mu \mathrm{g} / \mathrm{L}$, respectively (Table 6). The mean value was $778.21 \mu \mathrm{g} / \mathrm{L}$, which is approximately 40 times greater than the ITASHY and WHO standard value. Cobalt is a rare element in the earth's crust and thus not typically found in high concentrations in surface waters. Thus, no standard value has been set for this chemical and for its compounds despite the fact that they are extremely toxic for humans (Okumusoglu 2009). Zn values ranged between 438 and $16270 \mu \mathrm{g} / \mathrm{L}$ (mean 4374.95). Total Cd levels ranged between 0.9 and $29.1 \mu \mathrm{g} / \mathrm{L}$ (mean 12.59), which exceeds all national and international standard values of $5 \mu \mathrm{g} / \mathrm{L}$. The $\mathrm{Pb}$ levels in AMLs ranged between 0.1 and $3 \mu \mathrm{g} / \mathrm{L}$ (mean 1.1).

\section{Limnology of AML 2}

Morphological and some chemical properties of AML no. 2 were studied during July 2010 (Fig. 13). The bathymetry of the lake was measured using a 30-m marine rope marked at $1-\mathrm{m}$ intervals that was tied to a $1-\mathrm{kg}$ weight. Lake depth was measured at $15-\mathrm{m}$ intervals along a $235-\mathrm{m}$ long transect (A-A') across the longest part of the lake for a total of 15 depth measurements (Fig. 14). The deepest point in the lake was $13.45 \mathrm{~m}$ deep, and the average depth of the lake was $7.41 \mathrm{~m}$ (Fig. 15). The perimeter and surface area of the lake were 616 and $15.55 \mathrm{~m}^{2}$, respectively. $\mathrm{pH}$ concentrations increased as depth increased; the average $\mathrm{pH}$ was
Fig. 15 The vertical profile on A- $\mathrm{A}^{1}$ cross-section

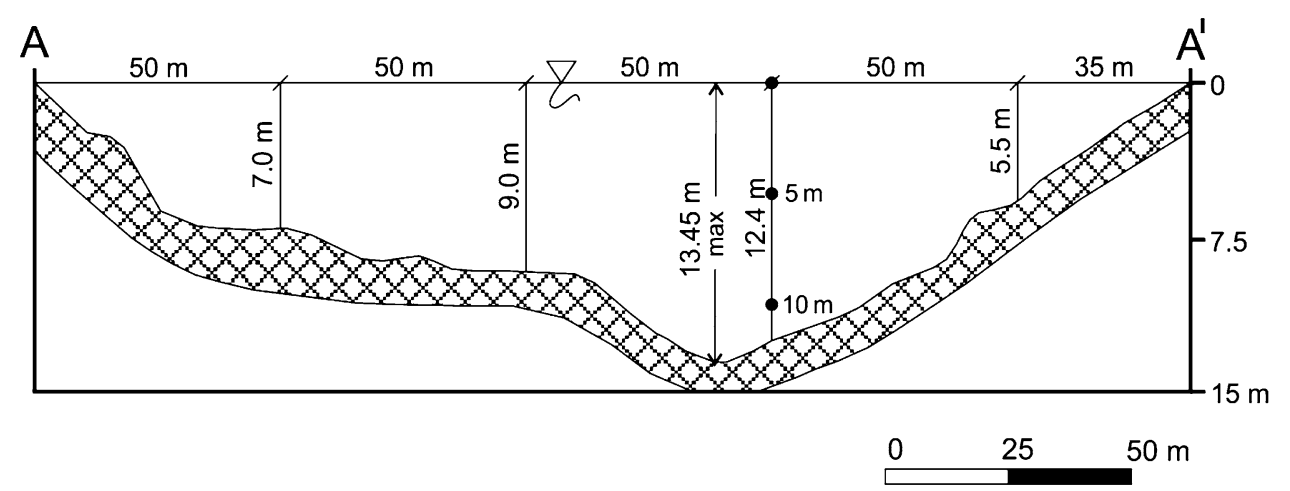





Fig. 16 Environmental impacts of AMD in study area

3.32. Iron concentrations ranged between 328.29 and $461.83 \mathrm{mg} \mathrm{L}^{-1}$, and concentrations increased with depth.

\section{Environmental Effects of AMLs}

Water contaminated by AMD, often containing increased concentrations of metals, can be toxic to aquatic organisms, leaving receiving streams devoid of most living creatures (Kimmel 1983). In addition, some metals bioaccumulate in the aquatic food chain.

The AMLs are located at the upstream areas of the Kocacay Stream, which passes through Etili village, Can and Biga counties, and eventually discharges into the Sea of Marmara to the north. Several residential areas along this stream system, including Keciagili, Etili, and Can, obtain drinking water from wells within the flood plain (Fig. 16). Thus, the water quality in Kocacay Stream and its tributaries have great importance for providing safe drinking water to the local residents.

$\mathrm{pH}$ values of the AMLs and surrounding creeks were between 2.85 and 5.75 (Fig. 17). The surrounding creeks drain into Katran Creek to the northeast, which is a tributary of Kocacay Stream. Coal-mining activity has caused the flow direction of some creeks to change in the study area.

One of the AMLs (AML no. 2) was discharged to Kocacay Stream in 2008, resulting in serious environmental problems. It is also worthwhile to mention that in Can Basin, some fish deaths have been observed because of the seepage and discharge of the AML waters into surface waters (Sanliyuksel and Baba 2011). However, this lake reoccurs from time to time over very short periods.

The majority of this type of pollution results from old mining operations that have simply been abandoned after coal was extracted in the study area. The open-pit coal mines, where waste rocks are placed around the mining area, are exposed to weathering and leaching by rain. The tailings and altered volcanic rocks around mining area are composed of various kinds of minerals containing high amounts of heavy metals. Metals in the altered rocks and tailings can be released by the low-pH AMD and transported by rainwater, surface water, and groundwater away from the mine. Residual-waste crushed rock from mining activities represents a major source for metal-rich AMD water. The tailing minerals can release metal ions over long time periods due to oxidation of sulfide minerals leading to the production of sulfuric acid. In addition, groundwater moves from the topographically high tributary-watershed areas (Piren Hill) toward the topographically lower areas (coal mine sites) (Fig. 18).

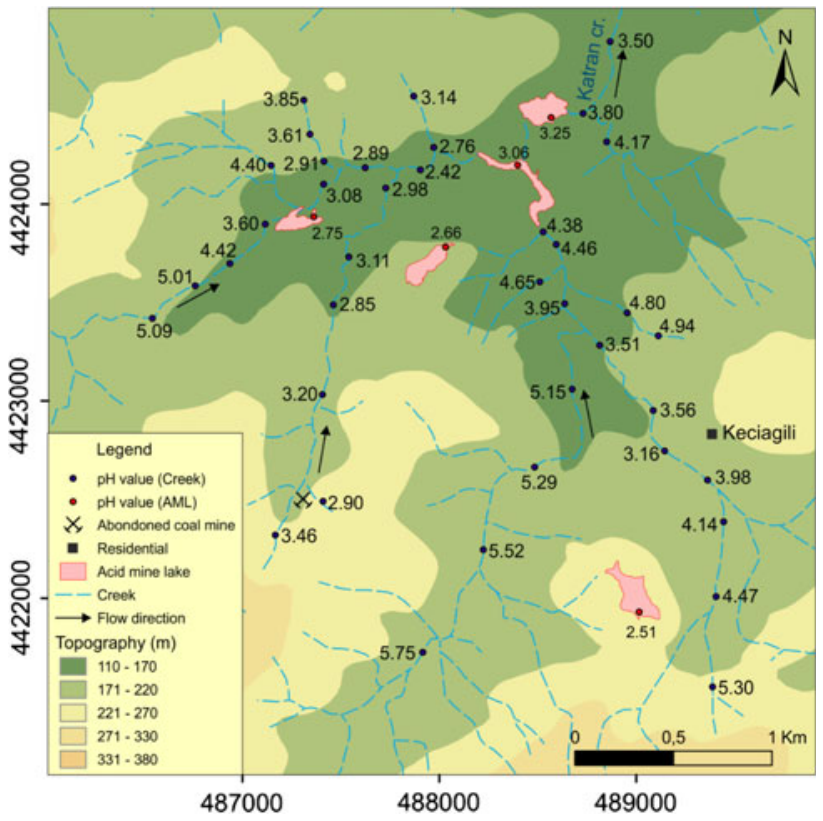

Fig. 17 pH distribution of creeks and AMLs (May 2012) 


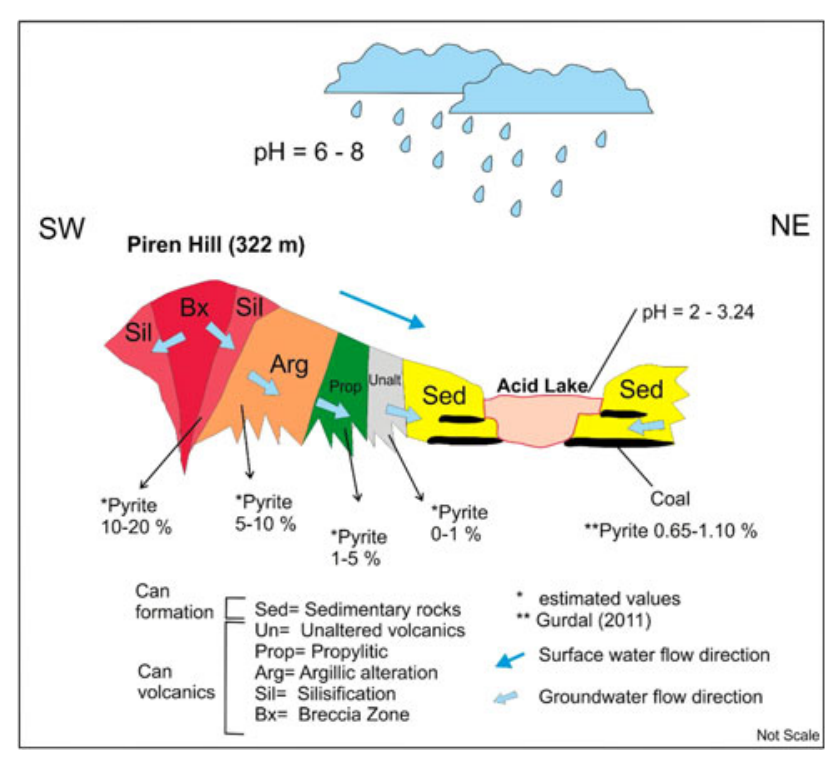

Fig. 18 A simplified conceptual model of AML

\section{Conclusion}

This study focused on characterizing the geochemistry and mineralogy of AMD from the Can region, northwest Turkey. $\mathrm{FeS}_{2}$ is the main cause of water pollution originating from abandoned coal mine deposits. Oxidation of $\mathrm{FeS}_{2}$ gives rise to the generation of AMD, which is one of the most significant environmental consequences of mining operations, especially tailing dumps. These acidic waters can typically dissolve metals, metalloids, and other toxic materials and pose many environmental problems. Therefore, the study of the geochemistry of $\mathrm{FeS}_{2}$ and its oxidation regarding AMD generation can help in devising minemanagement plans to help minimize the environmental impact associated with AMD. Based on the results of this study, the lakes exhibited characteristics typical of AMLs, including reddish-brown color, low $\mathrm{pH}$, and high heavymetal and trace-element concentrations. The concentrations of $\mathrm{Al}, \mathrm{Fe}$, and $\mathrm{Mn}$ were found to exceed national and international water-quality standards.

Management of AMD aims to decrease the impact of the effluent to levels that can be tolerated by the environment without significant damage. To minimize this pollution, precautions must be taken to ensure that rainwater does not come into contact with $\mathrm{FeS}_{2}$. Abandoned waste and lack of rehabilitation measures on closure could be considered as the consequence of poor mining operations. Particularly, in mining areas with high $\mathrm{FeS}_{2}$ content, special precautionary measures should always be implemented on completion of the operational phase of mining to prevent degradation of water quality and the environment.
Both the AMLs and Can county suffer from the same hydrochemical problem: the oxidation of sulfide minerals in mine waste and consequent acidification of mining lakes and leaching of metals from the sediment and groundwater. Therefore, it is very important to monitor the effect of this wastewater on water resources and soil.

Acknowledgments The authors are grateful to Mehmet ali Yucel and Firat Sengun for their support for field studies and suggestions and Mehmet Karadeniz for helpful comments. Herb Maier is acknowledged for proofreading and suggestions. This research was funded by the Teck Mining Company and partially supported by the Canakkale Onsekiz Mart University, Scientific Research Project No. 2011/082.

\section{References}

Abel A, Michael A, Zartl A, Werner F (2000) Impact of erosiontransported overburden dump materials on water quality in Lake Cospuden evolved from a former open cast lignite mine south of Leipzig, Germany. Environ Geol 39(6):683-688

Akcil A, Ciftci H (2003) Effect of sulphur and iron-oxidizing bacteria on metal recovery in leaching of Kure pyritic copper ore [in Turkish]. Bull Earth Sci Appl Res Center Hacattepe Univ $28: 145-154$

Akcil A, Koldas S (2006) Acid mine drainage (AMD): causes, treatment and case studies. J Clean Prod 14:1139-1145

Allan R (1997) Introduction: mining and metals in the environment. J Geochem Explor 58:95-100

Alpers CN, Nordstrom DK, Burchard JM (1992) Compilation and interpretation of water quality and discharge for acidic waters at Iron Mountain, Shasta County, California. United States Geological Survey Bulletin No pp 91-4150

Anderson WC, Youngstrom MP (1976) Coal pile leachate-Quantity and quality characteristics. J Environ Eng Div ASCE 102:1239-1253

Aytekin Y, Akdagi M (1996) The investigation of Eastern Black Seatype copper-lead-zinc hydrometallurgical process evaluation (Rize-Cayeli sample) TUBITAK Supported Project No. 501 VIII

Baba A, Gunduz O (2009) Coal mining, energy production and environment: local aspects of a global dilemma. In: Baba A, Helvac1 C, Tayfur G (eds) Proceedings of the AASA workshop on environment and resources, pp 56-64

Baba A, Gunduz O (2010) Effect of alteration zones on water quality: a case study from Biga Peninsula, Turkey. Arch Environ Contam Toxicol 58(3):499-513

Baba A, Gurdal G, Sengunalp F, Ozay O (2007) Effects of leachant temperature and $\mathrm{pH}$ on leachability of metals from fly ash. A case study: can thermal power plant, province of Canakkale, Turkey. Environ Monit Assess 139:287-298

Baba A, Save D, Gunduz O, Gurdal G, Bozcu M, Sulun S et al (2009) The assessment of the mining activities in Can Coal Basin from a medical geology perspective [in Turkish]. Final Report of The Scientific and Technological Research Council of Turkey (TUBITAK), Project No. CAYDAG-106Y041, Ankara, Turkey

Bachmann TM, Friese K, Zachmann DW (2001) Redox and $\mathrm{pH}$ conditions in the water column and in the sediments of an acidic mining lake. J Geochem Explor 73:75-86

Blodau C (2006) A review of acidity generation and consumption in acidic coal mine lakes and their watershed. Sci Total Environ 639:307-332 
Blodau C, Hoffmann S, Peine A, Peiffer S (1998) Iron and sulfate reduction in the sediments of acidic mine lake 116 (Brandenburg, Germany): rates and geochemical evaluation. Water Air Soil Pollut 108(3-4):249-270

Bozcu M, Akgun F, Gurdal G, Yesilyurt SK, Karaca O (2008) Sedimentologic, petrologic, geochemical and palinologic examination of Can Yenice Bayramic (Canakkale) lignite basin [in Turkish]. Final Report of The Scientific and Technological Research Council of Turkey (TUBITAK), Project No. CAYDAG-105Y114, Ankara, Turkey

Brake SS, Dannelly HK, Connors KA (2001) Controls on the nature and distribution of an alga in coal mine-waste environments and its potential impact on water quality. Environ Geol 40(4-5):458-469

British Columbia Acid Mine Drainage Task Force (1989) Draft acid rock drainage technical guide, vol 1. Prepared by Robertson S, Kirsten SRK. Vancouver BC Canakkale Meteorological Station 2010, Weather Forecast, Canakkale, Turkey

Cravotta CA III (1991) Geochemical evolution of acidic ground water at a reclaimed surface coal mine in western Pennsylvania. In: Oaks WR, Bowden J (eds) Proceedings of the 1991 National Meeting of the American Society of Surface Mining and Reclamation, May 14-17. American Society of Surface Mining and Reclamation, Durango Co, pp 43-68

Cravotta AC (2008) Dissolved metals and associated constituents in abandoned coal-mine discharges, Pennsylvania, USA. Part 1: constituent quantities and correlations. Appl Geochem 23:166-202

Cravotta CAI, Brady KBC, Rose AW, Douds JB (1999) Frequency distribution of the $\mathrm{pH}$ of coal-mine drainage in Pennsylvania. In: Morganwalp DW (ed) US Geological Survey Toxic Substances Hydrology Program. Proceedings of a technical meeting, United States Geological Survey, Water-Resources Investigation 313-324, Report 99-4018A

Davis EC, Boegly WJ (1981) A review of water quality issues associated with coal storage. J Environ Qual 10:127-133

Davis A, Ruby MV, Bloom M, Schoof R, Freeman G, Bergstrom PD (1991) Mineralogic constraints on the bioavailability of arsenic in smelter-impacted soils. Environ Sci Techol 30:392-399

Delaloye M, Bingol E (2000) Granitoids from western and northwestern Anatolia: geochemistry and modelling of geodynamic evolution. Int Geol Rev 42:241-268

Devasahayam S (2006) Chemistry of acid production in black coal mine washery wastes. Int J Miner Process 79:1-8

Doulati AF, Jodeiri SB, Bagheri M, Soleimani E (2010) Investigation of pyrite oxidation and acid mine drainage characterization associated with Razi active coal mine and coal washing waste dumps in the Azad Shahr-Ramian region, northeast Iran. Environ Earth Sci 61:1547-1560

Dutrizac JE, Jambor JL (2000) Jarosites and their application in hydrometallurgy, sulfate minerals - crystallography, geochemistry, and environmental significance. In: Alpers CN, Jambor JL, Nordstrom DK (eds) Miner Soc Am Rev Miner Geochem 40:405-443

Ercan T, Satir M, Steinitz G, Dora A, Sarifakioglu E, Adis C et al (1995) Characteristics of the Tertiary volcanism in the Biga Peninsula, Gokceada, Bozcaada and Tavsanadasi, NW Anatolia [in Turkish]. MTA Bull 117:55-86

Erickson P, Heiden R (1988) Evaluation of overburden analytical methods as a means to predict post-mining coal mine drainage quality. In: Conference proceedings mine drainage and surface mine reclamation, United States Bureau of Mines Information Circular 9183, vol 1, pp 11-20

Espana JS, Pamo EL, Pastor ES, Ercilla MD (2008) The acidic mine pit lakes of the Iberian Pyrite Belt: an approach to their physical limnology and hydrogeochemistry. Appl Geochem 23:12601287

Evangelou VP, Zhang YL (1995) A review: pyrite oxidation mechanisms and acid mine drainage prevention. Crit Rev Environ Sci Technol 25(2):141-199

Foos A (1997) Geochemical modeling of coal mine drainage, Summit Co. Ohio. Environ Geol 31(3/4):205-210

Goldbery R (1978) Early diagenetic nonhydrothermal sodium alunite in Jurassic flint clays, Makhtesh Ramon, Israel. Geol Soc Am Bull 89:687-698

Gryaznov VI (1957) Minerals of the alunite-jarosite group from clays of the Kharkov series. Nauch Zap Dnepropetrovsk Gosudarst University. Sbornik Rabot Nauch-Issledovatel Inst Geol 58:79-85 (Chem Abs 54:24155)

Gunduz O, Okumusoglu D, Baba A (2007) Acidic mining lakes and their influence on water quality: a case study from Can (Canakkale), Turkey. In: Proceedings of groundwater quality 2007: securing groundwater quality in urban and industrial environments, 6th international groundwater quality conference, Fremantle, Western Australia

Gurdal G (2008) Geochemistry of trace elements in Can coal (Miocene), Canakkale, Turkey. Int J Coal Geol 74:28-40

ITASHY (2005) Regulation on waters intended for human consumption [in Turkish]. Official Gazette dated 17/02/2005, No. 25730, Ankara, Turkey

Jambor JL, Blowes DW (1994) Environmental geochemistry of sulfide mine-wastes. Mineralogical Association of Canada Short Course Handbook. Nepean, Ontario, p 22

Jennings SR, Neuman DR, Blicker PS (2008) Acid mine drainage and effects on fish health and ecology: a review. Reclamation Research Group Publication, Bozeman

Kesimal A, Yilmaz E, Ercikdi B, Alp I, Yumlu M, Ozdemir B (2003) Paste backfill technology in underground mining-a case study. Earth Sci J Istanbul Univ Eng Faculty 6(1):45-53

Khlybov VV (1976) Jarosite from the oxidation zone of pyritized rocks of the western Pritimanye. Trudy Inst Geol Komi Fil Akad Nauk SSSR 20:65-71

Kim JJ, Kim SJ (2004) Seasonal factors controlling mineral precipitation in the acid mine drainage at Donghae coal mine, Korea. Sci Total Environ 325:181-191

Kimmel WG (1983) The impact of acid mine drainage on the stream ecosystem. Resources, technology, and utilization. Pennsylvania Academic Science Publications, Pennsylvania coal, pp 424-437

Krazewski SR (1972) Jarosite from Pliocene deposits in Wloclawek. Arch Miner 30(1):5-12

Lapakko K (2002) Metal mine rock and waste characterisation tools: an overview of mining, minerals and sustainable development. Report No. 67. Acid Drainage Technology Initiative. www.mackay.unr.edu/adti

Larsen D, Mann R (2005) Origin of high manganese concentrations in coal mine drainage, eastern Tennessee. J Geochem Explor $86: 143-163$

Leathen WW, Braley SA, McIntyre LD (1953) The role of bacteria in the formation of acid from certain sulfuric constituents associated with bituminous coal, II. Ferrous-iron oxidizing bacteria. Appl Microbiol 1:65-68

Lessmann D, Deneke R, Ender R, Hemm M, Kapfer M, Krumbeck H et al (1999) Lake Plessa 107 (Lusatia, Germany) - An extremely acidic shallow mining lake. Hydrobiologia 408(409):293-299

Lessmann D, Uhlmann W, Gunewald U, Nixdorf B (2003) Sustainability of the flooding of lignite mining lakes as a remediation technique against acidification in the Lusatian mining district, Germany. Proceedings of the 6th International Conference on Acid Rock Drainage (ICARD), Cairns, Australia 14-17 July, pp 521-527 
Lin Z (1997) Mineralogical and chemical characterization of wastes from the sulfuric acid industry in Falun, Sweden. Environ Geol 30(3-4):152-162

Lin Z, Herbert RB Jr (1997) Heavy metal retention in secondary precipitates from a mine rock dump and underlying soil, Dalarna, Sweden. Environ Geol 33(1):1-12

Long DT, Fegan NE, Lyons WB, Hines ME, Macumber PG, Giblin AM (1992) Geochemistry of acid brines-Lake Tyrrell, Victoria, Australia. Chem Geol 96(1-2):33-52

Lottermoser BG (2010) Mine wastes: characterization, treatment and environmental impacts, 3rd edn. Springer-Verlag, Berlin

Malmstrom ME, Destouni G, Banwart SA, Stromberg BHE (2000) Resolving the scale-dependence of mineral weathering rates. Environ Sci Technol 34(7):1375-1378

McCleary EC, Kepler DA (1994) Ecological benefits of passive wetland treatment systems designed for acid mine drainage: with emphasis on watershed restoration. In: The international land reclamation and mine drainage conference and the third international conference on the abatement of acidic drainage. Pittsburgh, PA, April 24-29, pp 111-119

Merritt RD (1986) Coal geology and resources of the Susitna Lowland, Alaska. Alaska Division of Geological and Geophysical Surveys Public Data File 86-75

Mills C (1995) An AMD/ARD dedicated blog based on the text of a presentation given Mills to British Columbia high school science teachers. At a seminar on Acid Rock Drainage at the Cordilleran Roundup, held at the Hotel Vancouver, Vancouver, BC

Monterroso C, Macias F (1998) Drainage waters affected by pyrite oxidation in a coal mine in Galicia-NW Spain: composition and mineral stability. Sci Total Environ 216:121-132

Morrison JL (1988) A study of factors controlling the severity of acid mine drainage in the Allegheny Group of Western Pennsylvania. PSU, University Park, PA, Master's thesis

Nesbitt HW, Jambor JL (1998) Role of mafic minerals in neutralizing ARD, demonstrated using a chemical weathering methodology. In Cabri LJ, Vaughan DJ (eds) Modern approaches to ore and environmental mineralogy. Mineralogical Association of Canada Short Course Series, vol 27, pp 403-421

Neuendorf KKE, Mehl JP Jr, Jackson A (2005) Glossary of geology. American Geological Institute, Alexandria

Nordstrom DK, Alpers CN (1998) Geochemistry of acid mine waters, part A-Processes, techniques and health. In: Plumlee G, Logsdon M (eds) Environmental geochemistry of mineral deposits. Rev Econ Geol, Volume 6a. Soc Econ Geol, Chapter 6

Nordstrom DK, Ball JW (1986) The geochemical behavior of aluminum in acidified surface waters. Science 232:54-56

Nordstrom DK, Plummer LN, Wigley TML, Wolery TJ, Ball JW (1979) A comparison of computerized chemical models for equilibrium calculations in aqueous systems. In: Jenne EA (ed) Chemical modeling in aqueous systems. American Chemical Society Symposium Series, vol 93. ACS, Washington, DC, pp 857-892

Okay AI, Goncuoglu MC (2004) The Karakaya complex: a review of data and concepts. Trans J Earth Sci 13:75-95

Okay AI, Satir M (2000) Coeval plutonism and metamorphism in a latest Oligocene metamorphic core complex in northwest Turkey. Geol Mag 137:495-516

Okay AI, Siyako M, Burkan KA (1990) Geology and tectonic evaluation of the Biga peninsula [in Turkish]. TAPG Bull 2(1):83-121

Okumusoglu D (2009) The influence of mining activities on surface and subsurface water quality. Master's thesis, The Graduate School of Natural and Applied Sciences of Dokuz Eylul University (unpublished)

Ozcelik GA (2007) Prediction techniques of acid mine drainage: a case study of a new poly- metallic mine development in
Erzincan-Ilic, Turkey. Doctoral thesis, Middle East Technical University, Ankara, Turkey

Paktunc AD (1999) Characterization of mine wastes for prediction of acid mine drainage. In: Azcue JM (ed) Environmental impacts of mining activities. Springer-Verlag, Berlin, pp 19-39

Plumlee GS (1999) The environmental geology of mineral deposits. In: Plumlee GS, Logsdon JJ (eds) The environmental geochemistry of mineral deposits. Part A: processes, techniques, and health issues. Soc Econ Geol Rev Econ Geol 6A:71-116

Pluta I, Jackowicz-Korczynski J (2003) Acid mine process in Polish coal mines: the Niwka-Modrzejow coal mine example. In: Nel PJL (ed) Mine water and the environment. In: Proceedings of 8th international mine water association congress, Johannesburg, South Africa, pp 37-41

Price WA (2003) Challenges posed by metal leaching and acid rock drainage at closed mines. British Columbia Technical and Research Committee on Reclamation. http://www.hsph.harvard. edu/mining/files/Canadian_paper_on_challenges_facing_metal_ mines_with_suggestions.pdf. Accessed January 92012

Rose AW, Cravotta CAIII (1998) Geochemistry of coal-mine drainage. In: Brady KBC, Smith MW, Schueck JH (eds) Coal mine drainage prediction and pollution prevention in Pennsylvania. Pennsylvania Department of Environmental Protection, Harrisburg, PA, 5600-BK-DEP2256, chap 1, pp 1-22

Salomons W (1995) Environmental impact of metals derived from mining activities: processes, predictions, prevention. J Geochem Explor 52:5-23

Sanliyuksel D, Baba A (2011) Effects of the abandoned mining wastes on water resources in Can Basin, 64th Geological Congress of Turkey. Ankara, Turkey, pp 47-48

Sanliyuksel Yucel D, Sengun F, Baba A (2012) Effects of alteration zones on water resources in Can Basin, 65th Geological Congress of Turkey. Ankara, Turkey, pp 122-123

Sengun F, Yigitbas E, Tunc IO (2011) Geology and tectonic emplacement of Eclogite and Blueschists, Biga Peninsula, Northwest Turkey. Turk J Earth Sci 20(3):273-285

Shevenell L, Connors KA, Henry CD (1999) Controls on pit lake water quality at sixteen open-pit mines in Nevada. Appl Geochem 14:669-687

Silva LFO, Wollenschlager M, Oliveira MLS (2011a) A preliminary study of coal mining drainage and environmental health in the Santa Catarina region, Brazil. Environ Geochem Health 33:55-65

Silva LFO, Oliveira MLS, Neace ER, O'Keefe JMK, Henke KR, Hower JC (2011b) Nanominerals and ultrafine particles in sublimates from the Ruth Mullins coal fire, Perry County, Eastern Kentucky, USA. Int J Coal Geol 85:237-245

Siyako M, Burkan KA, Okay AI (1989) Tertiary geology and hydrocarbon potential of the Biga and Gelibolu peninsulas [in Turkish]. Turkish Petrol Geolo Assoc Bull 1(3):183-200

Skousen JG, Ziemkiewicz PF (1995) Acid mine drainage control and treatment. West Virginia University, Morgantown

Sola C, Burgos M, Plazuelo A, Toja J, Plans M, Prat N (2004) Heavy metal bioaccumulation and macroinvertebrate community changes in a Mediterranean stream affected by acid mine drainage and an accidental spill (Guadiamar river, SW Spain). Sci Total Environ 333:109-126

Sracek O, Choquette M, Gelinas P, Lefebvre R, Nicholson RV (2004) Geochemical characterization of acid mine drainage from a waste rock pile, Mine Doyon, Quebec, Canada. J Contam Hydrol 69:45-71

Stromberg B, Banwart S (1999) Weathering kinetics of waste rock from the Aitik copper mine, Sweden: scale dependent rate factors and $\mathrm{pH}$ controls in large column experiments. J Contam Hydrol 39(1-2):59-89

Stumm W, Morgan JJ (1970) Aquatic chemistry. Wiley, New York 
Stumm W, Morgan JJ (1995) Aquatic chemistry: chemical equilibria and rates in natural waters. Wiley, New York

Triantafyllidis S, Skarpelis N (2006) Mineral formation in an acid pit lake from a high-sulfidation ore deposit: Kirki, NE Greece. J Geochem Explor 88:68-71

United States Environmental Protection Agency (1994a, April) Innovative methods of managing environmental releases at mine sites. USEPA, Office of Solid Waste, Special Wastes Branch (Washington DC), OSW Doc. 530-R-94-012

United States Environmental Protection Agency (1994b, December) Acid mine drainage prediction. USEPA, Office of Solid Waste, Special Wastes Branch (Washington DC), EPA 530-R-94-036

United States Environmental Protection Agency (2003) Environmental Protection Agency Office of Water national primary drinking water standards. USEPA, EPA 816-F-03-016, Washington DC, USA

Warshaw CM (1956) The occurrence of jarosite in underclays. Am Miner 41:288-296

Weber L (2000) Modellierung von Porenwasserprofilen in sauren Bergbaurestseen unter Berücksichtigung der advektiven Strömung im Sediment. Doctoral thesis, Universität Heidelberg, Heidelberg, Germany

Wood SC, Younger PL, Robins NS (1999) Long-term changes in the quality of polluted minewater discharges from abondoned underground coal workings in Scotland. Q J Eng Geol 32:69-79
World Health Organization (2004) World Health Organization Guidelines for drinking water quality, 3rd edn, vol 1. WHO, Geneva

Yigit O (2009) Mineral deposits of Turkey in relation to Tethyan metallogeny: implications for future mineral exploration. Econ Geol 104(1):19-51

Yigit O (2012) A prospective sector in the Tethyan metallogenic belt: geology and geochronology of mineral deposits in the Biga Peninsula, NW Turkey. Ore Geol Rev 46:118-148

Younger PL (1995) Hydrogeochemistry of mine waters flowing from abandoned coal workings in County Durham. Q J Eng Geol 28:101-113

Yucel MA, Sanliyuksel Yucel D (2012) Determining and visualization of border changing on coal mining activities with satellite images and geographic information system (GIS) in Can (Canakkale) County [in Turkish]. Canakkale Onsekiz Mart University Scientific Research Project, Project No. BAP 2011/082

Yucel MA, Sanliyuksel Yucel D, Baba A (2012) Determining of border changing on coal mining activities with satellite images on the environment of geographic information system (GIS) in Can (Canakkale) County, 65th Geological Congress of Turkey, Ankara 146-147 